The original publication is available at www.springerlink.com

\title{
Preliminary global assessment of biodiversity consequences of sea level rise mediated by climate change
}

\author{
Shaily Menon • Jorge Soberón • Xingong Li • A. Townsend Peterson
}

S. Menon

Department of Biology, Grand Valley State University, Allendale, Michigan 49401-9403 USA, menons@gvsu.edu

J. Soberón

Natural History Museum and Biodiversity Research Center, The University of Kansas, Lawrence, Kansas 66045 USA

X. Li

Department of Geography, The University of Kansas, Lawrence, Kansas 66045 USA

A. T. Peterson

Natural History Museum and Biodiversity Research Center, The University of Kansas, Lawrence, Kansas 66045 USA

Corresponding Author:

A. Townsend Peterson

Tel: (785) 864-3926

Fax: (785) 864-5335

Email: town@ku.edu 


\section{3}

44

45

46

47

48

49

50

51

52

53

54

Running Title: Biodiversity consequences of sea level rise

\section{Preliminary global assessment of biodiversity consequences}

\section{of sea level rise mediated by climate change}

\section{Shaily Menon • Jorge Soberón • Xingong Li • A. Townsend Peterson}

Abstract Considerable attention has focused on the climatic effects of global climate change on biodiversity, but few analyses and no broad assessments have evaluated the effects of sea level rise on biodiversity. Taking advantage of new maps of marine intrusion under scenarios of $1 \mathrm{~m}$ and $6 \mathrm{~m}$ sea level rise, we calculated areal losses for all ecoregions globally, with areal losses for particular ecoregions ranging from nil to complete. Marine intrusion is a global phenomenon, but is most prominent in Southeast Asia and nearby islands, eastern North America, northeastern South America, and western Alaska. Making assumptions regarding responses to reduced distributional area by species endemic to ecoregions, we estimated likely numbers of extinction caused by sea level rise, and found that marine-intrusion-caused extinctions of narrow endemics is most prominent in northeastern South America, although anticipated extinctions in smaller numbers are scattered worldwide. This assessment serves as a complement to recent estimates of losses owing to changing climatic conditions, considering a dimension of biodiversity consequences of climate change that has not previously been taken into account. 
63 Keywords climate change, sea-level change, marine intrusion, biodiversity, ecoregions,

64 endemic species, extinction

65

66

\section{Introduction}

68 Considerable attention has focused on the biodiversity consequences of global climate change

69 (Peters and Darling 1985; Dobson et al. 1989; Lovejoy and Hannah 2005). In particular,

70 attention has focused on direct effects of changes in climatic conditions on species' ability to

71 persist in a region-if climate changes sufficiently that persistence is not possible, then either

72 movement to track appropriate conditions or extirpation are the only alternatives (Holt 1990).

73 The dimensions of biodiversity loss due to climate change are being outlined to varying degrees

74 of confidence, by both empirical observations of climate change effects (Parmesan 1996; Visser

75 et al. 1998; Parmesan et al. 1999; Pounds et al. 1999; Parmesan and Yohe 2003) and predictions

76 from ecological niche models based on general circulation model (GCM) outputs (Erasmus et al.

77 2002; Peterson et al. 2002; Thomas et al. 2004a; Araújo et al. 2005; Peterson et al. 2005; Anciães

78 and Peterson 2006), although the interpretation of model results in terms of extinction rates can

79 be complex (Buckley and Roughgarden 2004; Thuiller et al. 2004; Lewis 2006).

80 Another important dimension of climate change, however, is that of sea-level rise. The

81 factors contributing to this phenomenon are clearly complex, and future projections can vary

82 quite dramatically; still, best (though perhaps conservative) estimates are on the order of 0.5-1.0

$83 \mathrm{~m}$ (Carter et al. 2007), while others consider the complexity of the projections (Oerlemans et al.

84 2005), with some estimates much higher (Bindschadler 1998; Thomas et al. 2004b; Rignot and

85 Kanagaratnam 2006). Curiously, although considerable reflection and analysis has focused on 


9

this theme on the human and economic side (Titus 1990; Mimura 1999; Hitz and Smith 2004; Bosello et al. 2007), few analyses have addressed the biodiversity consequences of sea-level change: a few papers have addressed ecosystem adaptation to rising sea-level (McKee et al. 2007), one has analyzed the likely effects on a single endangered species (LaFever et al. 2007), and a few analyses have been developed regarding particular regions or affected taxa (Daniels et al. 1993; Galbraith et al. 2002; Gopal and Chauhan 2006).

To date, nonetheless, no global assessment has been developed. Such is the purpose of this contribution: to offer a first-pass global assessment of sea-level rise impacts on biodiversity. We caution at the outset that our inferences are limited by several factors-imprecise estimates of sea-level rise, difficulties in scenario-building at $<1 \mathrm{~m}$ sea-level rise, and lack of highresolution data on biodiversity distributions globally. Still, if proper precautions and caveats are considered, a first-order estimate is worth exploring, if only to assess the relative importance of sea-level changes as an additional threat to global biodiversity.

\section{Methods}

Sea-level rise scenarios and inundation delineation

Sea level rise over the past century has resulted largely from thermal expansion of the ocean, melting of mountain glaciers, and accelerated discharge of glacial ice from the ice sheets to the ocean (Dyurgerov and Meier 1997). Among these factors, ice sheet melt has potential for substantial global impacts. The Greenland Ice Sheet contains a volume of water equivalent to 6 m of sea level rise, and the West Antarctic Ice Sheet, an unstable ice sheet grounded well below sea level, contains a volume of water equivalent to $5 \mathrm{~m}$ of sea level rise (Bindschadler, 1998). 
Both are currently showing rapid increases in mass loss that will significantly increase sea level if such losses continue (Thomas et al., 2004; Rignot and Kanagaratam 2006). Shepherd and Wingham (2007) summarized the recent sea level contributions from the Greenland and Antarctic Ice Sheets, showing a modest but growing component of the current rate of sea level rise. Otto-Bliesner et al. (2006) indicate that warming and melting of the Greenland Ice Sheet and other circum-Arctic ice fields likely contributed 2.2-3.4 $\mathrm{m}$ of sea level rise during the Last Interglaciation. Overpeck et al. (2006) also indicate that the rate of future melting and related sea level rise could be faster than widely thought and estimate sea level rise from melting of polar ice sheets may reach 4 to $>6$ m similar to those of 130,000-127,000 yr ago by the year 2100 . In addition, actual flooding process involves levels of high water that can be several meters above mean sea level (Marbaix and Nicholis, 2007). Considering the sea level rises reported in the literature and the effects of tidal and storm surge, potential inundation areas were delineated in this study with two scenarios bracketing the likely range of sea level rises of 1 and $6 \mathrm{~m}$; the vertical resolution of the global digital elevation model prohibits calculations of $<1 \mathrm{~m}$. Geographical information systems (GIS) has been used in several previous studies to delineate potentially inundated areas resulting from projected sea level rises (Dasgupta et al. 2007; LaFever et al. 2007). In these analyses, inundation areas are identified if their elevation is below a projected sea level rise. Although the method is simple, it has two shortcomings. First, water connectivity is not considered when inundation areas are delineated. Some areas, though their elevation is below a projected sea level rise, should not be inundated if terrain barriers exist between the ocean and the areas. Second, some areas with elevations below the projected sea level rise are already inland water bodies, and therefore should not be included in calculations of 
131 newly inundated areas. Given these two shortcomings, simple GIS methods likely overpredict 132 potential inundation areas.

A new and more robust GIS analysis method developed by Li et al. (In press) was used in

134 this study to overcome the above shortcomings. In the method, cells below a projected sea level 135 rise are initially flagged. From the flagged cells, only those with connectivity to the ocean are 136 selected. The selected cells are then checked to see whether or not they are part of existing inland 137 water bodies. Only those cells that connect to the ocean and are not presently inland water are 138 designated as inundation cells. The method was implemented as several steps in a GIS raster 139 analysis framework. Details of the method are referred to Li et al. (In press).

141 Ecoregion areal loss estimates

142 The Terrestrial Ecoregions GIS Database and the Terrestrial Ecoregions Base Global Dataset 143 (Olson et al. 2001) were the source of geospatial data showing the global extent of ecoregions, as 144 well as providing data on numbers of endemic species in each ecoregion. Of the many variables 145 calculated and summarized for each of the 827 terrestrial ecoregions by Olson et al. (2001), we 146 used values for strict endemic species and near endemic species (summed across all terrestrial 147 vertebrate classes) in this analysis. We converted the vector-format terrestrial ecoregions 148 coverage into a grid, and estimated ecoregion areal loss resulting from marine intrusion by 149 overlaying it with the $1 \mathrm{~m}$ and $6 \mathrm{~m}$ inundation grids generated with the above GIS method and 150 performing raster map algebra. Each grid was projected to a global equal area projection 151 (Mollweide) at a 1000 m resolution. 
154 Extinction estimates

155 The areal reductions of ecoregions can be used to estimate biodiversity losses under certain sets 156 of assumptions - specifically, that species will respond to area available and habitable in certain, 157 predictable ways (MacArthur and Wilson 1967). The relationship between numbers of species 158 present and area under consideration (species-area relationship, or SAR) has been used 159 extensively for estimates of likely future extinctions in numerous situations (Brooks et al. 1997; 160 Brooks et al. 2002), although not without controversy (see Results and Discussion). In its 161 simplest form, the SAR is a steady-state relationship between number of species $(S)$ and area $(A)$ 162 often, although not always (Tjørve 2003) of the form, $S=c A^{z}$, where $c$ and $z$ are constants 163 estimated from the data.

164 In applications to calculating species’ losses owing to areal reductions, if the present 165 number of species $S_{\text {now }}$ is existing in an area $A_{\text {now }}$, which is reduced to $A_{\text {future, }}$ and if $c$ and $z$ 166 remain constant (assumed), then the number of species will eventually decrease to a new steady 167 state $S_{\text {future }}=S_{\text {now }}\left(A_{\text {future }} / A_{\text {now }}\right)^{\mathrm{z}}$ (May and Stumpf 2000; Pimm and Raven 2000). In the present 168 analyses, we calculated $A_{\text {future }}$ and $A_{\text {now }}$ as detailed above, and $S_{\text {now }}$ was taken as the sum of strict 169 endemics and near endemics from the Terrestrial Ecoregions Base Global Dataset (Olson et al. 170 2001). Estimating the constant $c$ is unnecessary for calculating species' losses via area reduction.

171 We estimated $z$ in two different ways: (1) as the overall SAR across all ecoregions globally, and 172 (2) SARs for 3 latitudinal bands (polar, $>50^{\circ} \mathrm{N}$ and $>50^{\circ} \mathrm{S}$; temperate, $23-50^{\circ} \mathrm{N}$ and $23-50^{\circ} \mathrm{S}$; 173 tropical, $23^{\circ} \mathrm{S}$ to $23^{\circ} \mathrm{N}$ ). We calculated $S_{\text {future }}$ for each ecosystem under the general $\mathrm{z}$ and the 174 latitude-specific $z$, and estimated confidence intervals for each $S_{\text {future }}$ calculation based on $z \pm(2 \times$ 175 standard error). We opted not to use Kinzig \& Harte’s (2000) corrections for endemicity for 176 reasons treated in Results and Discussion. 
Results and Discussion

179 Areal loss estimates globally were $0.7 \%$ of global land area under $1 \mathrm{~m}$ of sea level rise, and $1.5 \%$ 180 of global land area under $6 \mathrm{~m}$ of sea level rise. Proportional losses in ecoregions ranged from 181 very low to complete (100\%) under both scenarios of sea-level rise, although the higher nature of 182 loss estimates under the $6 \mathrm{~m}$ scenario is clear, with most affected ecoregions concentrated in 183 Southeast Asia and associated islands, northeastern South America, eastern North America, and 184 western Alaska (Fig. 1). Even under a $1 \mathrm{~m}$ sea-level rise scenario, 21 ecoregions are expected to 185 lose $>50 \%$ of their land area, which include 8 mangrove-dominated ecoregions, lowland forest 186 and scrub on 8 islands or island groups, plus 5 low-lying continental areas (Peninsular Malaysian 187 peat swamp forests, Orinoco Delta swamp forests, Marajó varzea, Orinoco wetlands, and 188 Esperance mallee; see summary in Appendix). As such, sea-level rise manifested as marine 189 intrusions is expected to have significant effects on terrestrial ecoregions (Figs. 2 and 3). Areal loss estimates for ecoregions can be translated into estimates of extinctions of 191 endemic and near-endemic taxa. Kinzig and Harte (2000) proposed methods to estimate the 192 fraction of a biota that would be strictly endemic to the lost area. In general, their methods give 193 smaller predictions than those obtained by application of the conventional SAR. However, their 194 methods assume that the shapes of the reduced areas are in a certain sense "well-behaved." In 195 particular, they present as an example of poorly-behaved areas long and narrow strips, which is 196 exactly the type of shape that sea-level rise causes. Besides, their methods require that the 197 reduced area is $\geq 50 \%$ of the original area, a condition not fulfilled in most of the ecoregions 198 analyzed herein. 
For the global SAR fitting, $z$ was estimated at $0.124 \pm 0.015$ s.e., although the overall fit

200

201

202

203

204

205

206

207

208

209

210

211

212

213

214

215

216

217

218

219

220

221

was not particularly tight $\left(R^{2}=0.15, N=827\right)$. Of a present standing set of 18,628 endemic or

near-endemic species in single ecoregions, this single SAR parameterization yielded a calculated loss of 117 (confidence interval 89-144) species for the $1 \mathrm{~m}$ sea-level rise scenario, and 221 (169-272) species for the $6 \mathrm{~m}$ scenario.

Splitting SAR regressions into polar, temperate, and tropical subsets, important regional differences were observed. The slope of the SAR $(z)$ was highest in tropical regions $(z=0.199 \pm$ 0.013), intermediate in temperate regions $(z=0.152 \pm 0.018)$, and lowest in polar regions $(z=$ $0.067 \pm 0.038)$. The scatter around these relationships was also reduced $\left(R^{2}=0.45, N=391 ; R^{2}=\right.$ $0.24, N=334 ; R^{2}=0.04, N=102$; respectively), suggesting that latitudinal effects explain part of the variation in the overall SAR (see also Drakare et al. 2006). These SAR differences translated into different rates of estimated species loss also: 0 of 35 polar species under both scenarios; 10 (8-13) and 30 (23-37) out of 3117 species under the $1 \mathrm{~m}$ and $6 \mathrm{~m}$ scenarios in temperate regions, respectively; and 170 (149-191) and 307 (269-344) out of 15,476 species under the $1 \mathrm{~m}$ and $6 \mathrm{~m}$ scenarios in tropical regions, respectively. Overall, then, with the regionspecific $z$ estimates, global species losses sum to 181 (157-204) species under the $1 \mathrm{~m}$ scenario and 337 (292-381) species under the 6 m scenario, out of 18,628 current species.

The use of SARs for estimating future extinctions has been criticized on a number of grounds (Drakare et al. 2006; Lewis 2006). (i) The value of $z$ is sometimes taken as a given from other studies, rather than fitted from the data; in this study, we calculated $z$ directly from ecoregion species richness data, and thus custom-fit the SAR to the data at hand. (ii) The value of $z$ is not solely dependent on area, but is also affected by latitude, taxonomic considerations, and other factors; we developed region-specific calculations that yielded dramatically different 
222 values of $z$; it was not feasible to take other considerations (e.g., taxon) into account. (iv) SAR

223 parameter values may change at different scales, which means that use of the simple equation

$224 S_{\text {future }}=S_{\text {now }}\left(A_{\text {future }} / A_{\text {now }}\right)^{\mathrm{Z}}$ may be flawed, since it is based on constant parameter values across

225 many scales. This criticism is important, as it affects every attempt to use SARs over spatial

226 scales spanning several orders of magnitude, and particularly at small areas, where SAR

227 behavior may become erratic (Lomolino 2000 ). However, as our dataset has $>98 \%$ of ecoregions

228 polygons $>10 \mathrm{~km}^{2}$, so the "small island" effect is probably not important. Finally (iv), simple

229 deforestation may not be a good surrogate for area loss, since deforested regions often still

230 maintain a matrix of habitats, some of which may remain habitable; in our case, area loss is

231 measured directly, without surrogates, so our analyses are less subject to this concern.

232 However, even with sea level rise, ecoregions may shrink or disappear, but also may

233 invade inland, effectively dispersing and transforming adjacent areas. For example, in regions

234 with shallow slopes, conditions suitable for mangrove growth may develop as inland areas

235 become new shorelines, thus compensating to some degree the losses. To address this

236 consideration, detailed modeling of how the process of sea intrusion creates new conditions as it

237 proceeds, and how ecosystems may or may not invade inland. We have not as-yet attempted such

238 steps, so our results must be considered as preliminary. An additional frustration is that the SAR-

239 based approach only estimates numbers of species likely to be lost, but does not inform regarding

240 which species are likely to be lost. Hence, overall, we consider our SAR application to assessing

241 species losses resulting from marine intrusion avoids many (if not all) of the common pitfalls

242 reported in the literature. Still, we point out that caution is warranted in interpreting these first

243 explorations of extinction consequences of marine intrusion. 
In sum, we present a first-pass global summary of likely biodiversity consequences of

245 sea-level rise and marine intrusion caused by climate change. The most realistic scenario of the

246 two we explored for sea-level rise is $1 \mathrm{~m}$, although the $6 \mathrm{~m}$ scenario is not outside of the range of

247 possibilities if uncertainties regarding the effects of glacial calving and ice-sheet loss turn out to

248 be worse than expected (Bindschadler 1998; Thomas et al. 2004b; Rignot and Kanagaratnam

249 2006). The losses estimated herein, interestingly, would be largely complementary to those

250 species lost based on climate change per se (i.e., climatic conditions becoming unsuitable for the

251 species), which have been explored in many recent publications (Peterson 2003; Thomas et al.

252 2004a; Thuiller et al. 2005; Araújo and Rahbek 2006; Thuiller et al. 2006). Moreover, our

253 analyses do not take into account second-order effects on biodiversity caused by humans affected

254 by rising sea levels, such as migrations and land use shifts which may cause yet more negative

255 effects on natural systems.

258 Literature Cited

259 Anciães M. and Peterson A.T. 2006. Climate change effects on Neotropical manakin diversity 260 based on ecological niche modeling. Condor 108: 778-791.

261 Araújo M.B., Pearson R.G., Thuiller W. and Erhard M. 2005. Validation of species-climate impact models under climate change. Glob Change Biol 11: 1504-1513.

263 Araújo M.B. and Rahbek C. 2006. How does climate change affect biodiversity? Science 313: 1396-1397.

265 Bindschadler R.A. 1998. Future of the west Antarctic ice sheet. Science 282: 428-429. 
Bosello F., Roson R. and Tol R. 2007. Economy-wide estimates of the implications of climate change: Sea level rise. Environmental and Resource Economics 37: 549-571.

Brooks T.M., Mittermeier R.A., Mittermeier C.G., da Fonseca G.A.B., Rylands A.B., Konstant W.R., Flick P., Pilgrim J., Oldfield S., Magin G. and Hilton-Taylor C. 2002. Habitat loss and extinction in the hotspots of biodiversity. Conservation Biology 16: 909-923.

Brooks T.M., Pimm S.L. and Collar N.J. 1997. The extent of deforestation predicts the number of birds threatened with extinction in insular South-east Asia. Conservation Biology 11: 382-394.

Buckley L.B. and Roughgarden J. 2004. Biodiversity conservation: Effects of changes in climate and land use. Nature 430.

Carter T.R., Jones R.N., Lu X., Bhadwal S., Conde C., Mearns L.O., O'Neill B.C., Rounsevell M.D.A. and Zurek M.B. 2007. New assessment methods and the characterization of future conditions.In: Parry M.L., Canziani O.F., Palutikof J.P., van der Linden P.J. and Hanson C.E., (eds.) Climate Change 2007: Impacts, Adaptation and Vulnerability. Cambridge University Press, Cambridge, U.K. p.^pp. 133-171.

Daniels R., White T. and Chapman K. 1993. Sea-level rise: Destruction of threatened and endangered species habitat in South Carolina. Environ Manage 17: 373-385.

Dasgupta S., Laplante B., Meisner C., Wheeler D. and Yan J. 2007. The Impact of Sea Level Rise on Developing Countries: A Comparative Analysis. World Bank, Washington, D.C.

Dobson A., Jolly A. and Rubenstein D. 1989. The Greenhouse Effect and biological diversity. Trends in Ecology and Evolution 4: 64-68.

Drakare S., Lennon J.J. and Hillebrand H. 2006. The imprint of the geographical, evolutionary and ecological context on species-area relationships. Ecology Letters 9: 215-227. 
Erasmus B.F.N., Van Jaarsveld A.S., Chown S.L., Kshatriya M. and Wessels K.J. 2002. Vulnerability of South African animal taxa to climate change. Glob Change Biol 8: 679693.

Galbraith H., Jones R., Park R., Clough J., Herrod-Julius S., Harrington B. and Page G. 2002. Global climate change and sea level rise: Potential losses of intertidal habitat for shorebirds. Waterbirds 25: 173-183.

Gopal B. and Chauhan M. 2006. Biodiversity and its conservation in the Sundarban Mangrove Ecosystem. Aquat Sci 68: 338-354.

Hitz S. and Smith J. 2004. Estimating global impacts from climate change. Global Environ Chang 14: 201-218.

Holt R.D. 1990. The microevolutionary consequences of climate change. Trends in Ecology and Evolution 5: 311-315.

Kinzig A.P. and Harte J. 2000. Implications of Endemics-Area Relationships for Estimates of Species Extinctions. Ecology 81: 3305-3311.

LaFever D.H., Lopez R.R., Feagin R.A. and Silvy N.J. 2007. Predicting the impacts of future sea-level rise on an endangered lagomorph. Environ Manage 40: 430-437.

Lewis O.T. 2006. Climate change, species-area curves and the extinction crisis. Philosophical Transactions of the Royal Society B: Biological Sciences 361: 163-171.

Li X., Rowley R.J., Kostelnick J.C., Braaten D. and Meisel J. In press. GIS analysis of global inundation impacts from sea level rise. Photogrammetric Engineering and Remote Sensing.

Lomolino M.V. 2000 Ecology's most general, yet protean pattern: the species area relationship. Journal of Biogeography 27: 17-26. 
312 313

314 315

Lovejoy T.E. and Hannah L., (eds.) 2005. Climate Change and Biodiversity. Yale University Press, New Haven, Conn.

MacArthur R.H. and Wilson E.O. 1967. The Theory of Island Biogeography. Princeton University Press, Princeton.

May R.M. and Stumpf M.P.H. 2000. Species-area relations in tropical forests. Science 290: 2084-2086.

McKee K.L., Cahoon D.R. and Feller I.C. 2007. Caribbean mangroves adjust to rising sea level through biotic controls on change in soil elevation. Global Ecology and Biogeography 16: 545-556.

Mimura N. 1999. Vulnerability of island countries in the South Pacific to sea level rise and climate change. Climate Res 12: 137-143.

Oerlemans J., Bassford R.P., Chapman W., Dowdeswell J.A., Glazovsky A.F., Hagen J.O., Melvold K., de Ruyter de Wildt M. and van de Wal R.S.W. 2005. Estimating the contribution of Arctic glaciers to sea-level change in the next 100 years Annals of Glaciology 42: 230-236.

Olson D.M., Dinerstein E., Wikramanayake E.D., Burgess N.D., Powell G.V.N., Underwood E.C., amico J.A., Itoua I., Strand H.E., Morrison J.C., Loucks C.J., Allnutt T.F., Ricketts T.H., Kura Y., Lamoreux J.F., Wettengel W.W., Hedao P. and Kassem K.R. 2001. Terrestrial Ecoregions of the World: A New Map of Life on Earth. BioScience 51: 933938.

Parmesan C. 1996. Climate and species' range. Nature 382: 765-766.

Parmesan C., Ryrholm N., Stefanescu C., Hill J.K., Thomas C.D., Descimon H., Huntley B., Kaila L., Kullberg J., Tammaru T., Tennent J., Thomas J.A. and Warren M. 1999. 
Poleward shift of butterfly species' ranges associated with regional warming. Nature 399: 579-583.

Parmesan C. and Yohe G. 2003. A globally coherent fingerprint of climate change impacts across natural systems. Nature 421: 37-42.

Peters R.L. and Darling J.D.S. 1985. The Greenhouse Effect and nature reserves. BioScience 35: 707-717.

Peterson A.T. 2003. Projected climate change effects on Rocky Mountain and Great Plains birds: Generalities of biodiversity consequences. Glob Change Biol 9: 647-655.

Peterson A.T., Ortega-Huerta M.A., Bartley J., Sánchez-Cordero V., Soberón J., Buddemeier R.H. and Stockwell D.R.B. 2002. Future projections for Mexican faunas under global climate change scenarios. Nature 416: 626-629.

Peterson A.T., Tian H., Martínez-Meyer E., Soberón J., Sánchez-Cordero V. and Huntley B. 2005. Modeling distributional shifts of individual species and biomes.In: Lovejoy T.E. and Hannah L., (eds.) Climate Change and Biodiversity. Yale University Press, New Haven, Conn. p.^pp. 211-228.

Pimm S.L. and Raven P. 2000. Extinction by numbers. Nature 403: 843-845.

Pounds J.A., Fogden M.P.L. and Campbell J.H. 1999. Biological response to climate change on a tropical mountain. Nature 398: 611-615.

Rignot E. and Kanagaratnam P. 2006. Changes in the velocity structure of the Greenland ice sheet. Science 311: 986-990.

Thomas C.D., Cameron A., Green R.E., Bakkenes M., Beaumont L.J., Collingham Y.C., Erasmus B.F.N., Ferreira de Siqueira M., Grainger A., Hannah L., Hughes L., Huntley B., Van Jaarsveld A.S., Midgely G.E., Miles L., Ortega-Huerta M.A., Peterson A.T., 
Phillips O.L. and Williams S.E. 2004a. Extinction risk from climate change. Nature 427: $145-148$.

Thomas R., Rignot E., Casassa G., Kanagaratnam P., Acuna C., Akins T., Brecher H., Frederick E., Gogineni P., Krabill W., Manizade S., Ramamoorthy H., Rivera A., Russell R., Sonntag J., Swift R., Yungel J. and Zwally J. 2004b. Accelerated sea-level rise from West Antarctica. Science 306: 255-258.

364

Thuiller W., Araujo M.B., Pearson R.G., Whittaker R.J., Brotons L. and Lavorel S. 2004. Biodiversity conservation: Uncertainty in predictions of extinction risk. Nature 430. 8245-8250. Namibia. Glob Change Biol 12: 759-776.

Thuiller W., Midgely G.F., Hughes G.O., Bomhard B., Drew G., Rutherford M.C. and

Thuiller W., Lavorel S., Araújo M.B., Sykes M.T. and Prentice I.C. 2005. Climate change threats to plant diversity in Europe. Proceedings of the National Academy of Sciences USA 102:

Tjørve E. 2003. Shapes and functions of speciesarea curves: A review of possible models. Journal of Biogeography 30: 827-835. 265: 1867-1870. 


\section{Figure Legends}

Fig. 1. Global summary of percent areal reduction across global ecoregions under a scenario of 6 $\mathrm{m}$ of sea-level rise (lightest pink $=0-5 \%$ loss, middle pink $=5-10 \%$ loss, strong pink $=$ $10-15 \%$ loss, red $=15-20 \%$ loss, dark red $20-50 \%$ loss, dark red-brown $=>50 \%$ loss) . Inset shows frequency distribution of areal losses under $1 \mathrm{~m}$ and $6 \mathrm{~m}$ scenarios of sea level rise.

Fig. 2. Left: Areal losses to ecoregions resulting from $1 \mathrm{~m}$ and $6 \mathrm{~m}$ sea level rise for portions of southeastern United States, Central America, the Caribbean, and northern South America. Ecoregions in this area predicted to suffer the greatest impacts include South Florida rocklands, Everglades, Piura mangroves, Para mangroves, Usumacinta mangroves, and Cuban mangroves. Right: Detail of the region surrounding the mouth of the Amazon River in South America, showing areal losses for ecosystems resulting from $1 \mathrm{~m}$ and $6 \mathrm{~m}$ scenarios of sea level rise.

Fig. 3. Left: Areal losses to ecoregions resulting from $1 \mathrm{~m}$ and $6 \mathrm{~m}$ sea level rise for portions of Asia and northern Australia. Ecoregions in this area predicted to suffer the greatest impacts include the Central Polynesian tropical moist forests, Indochina mangroves, and the New Guinea mangroves. Right: Detail of the region surrounding the Bay of Bengal, showing areal losses for ecosystems resulting from $1 \mathrm{~m}$ and $6 \mathrm{~m}$ scenarios of sea level rise. 


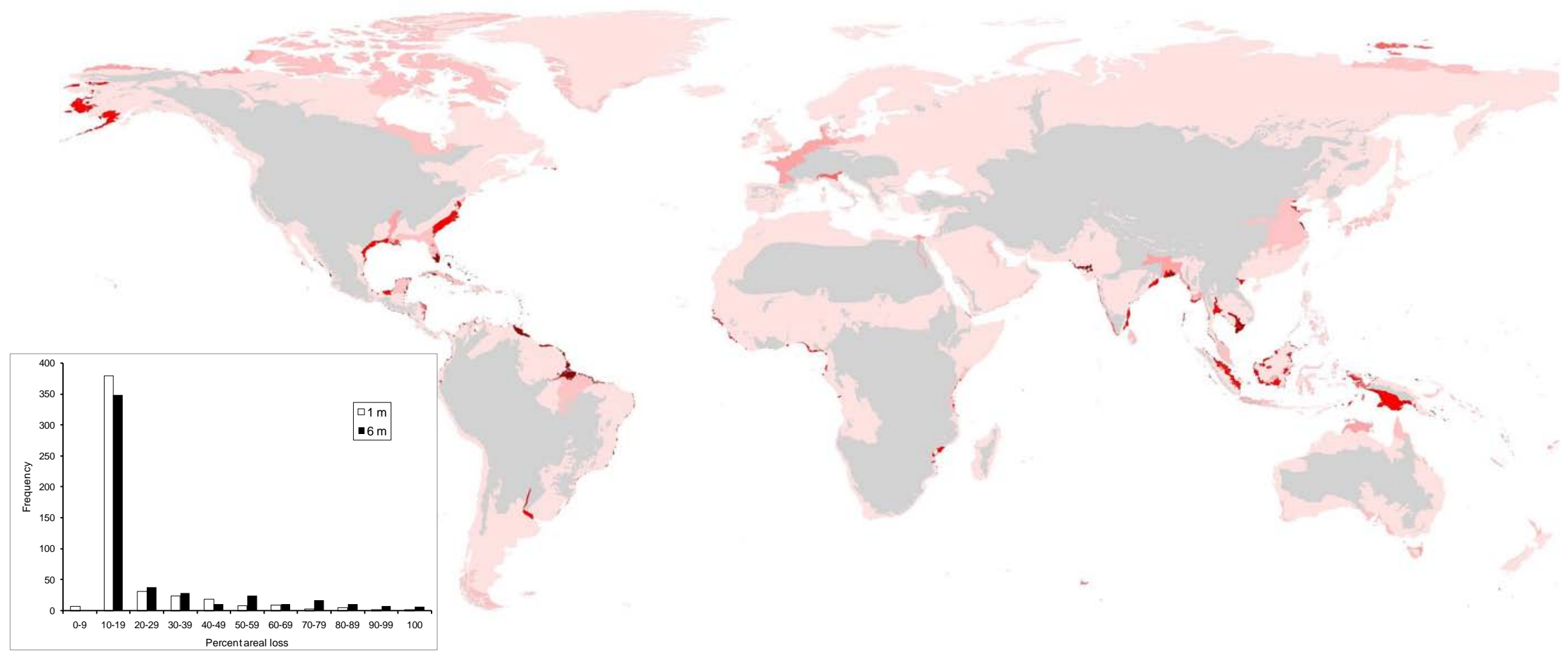




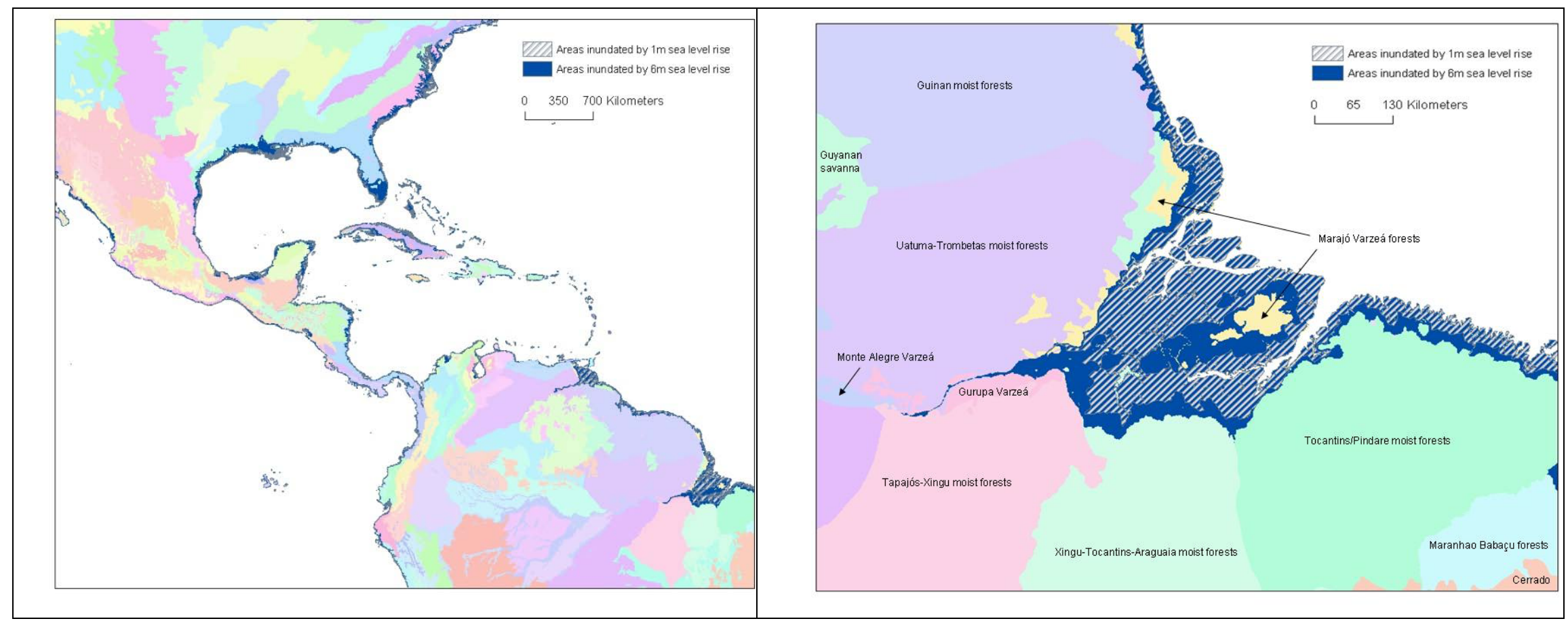




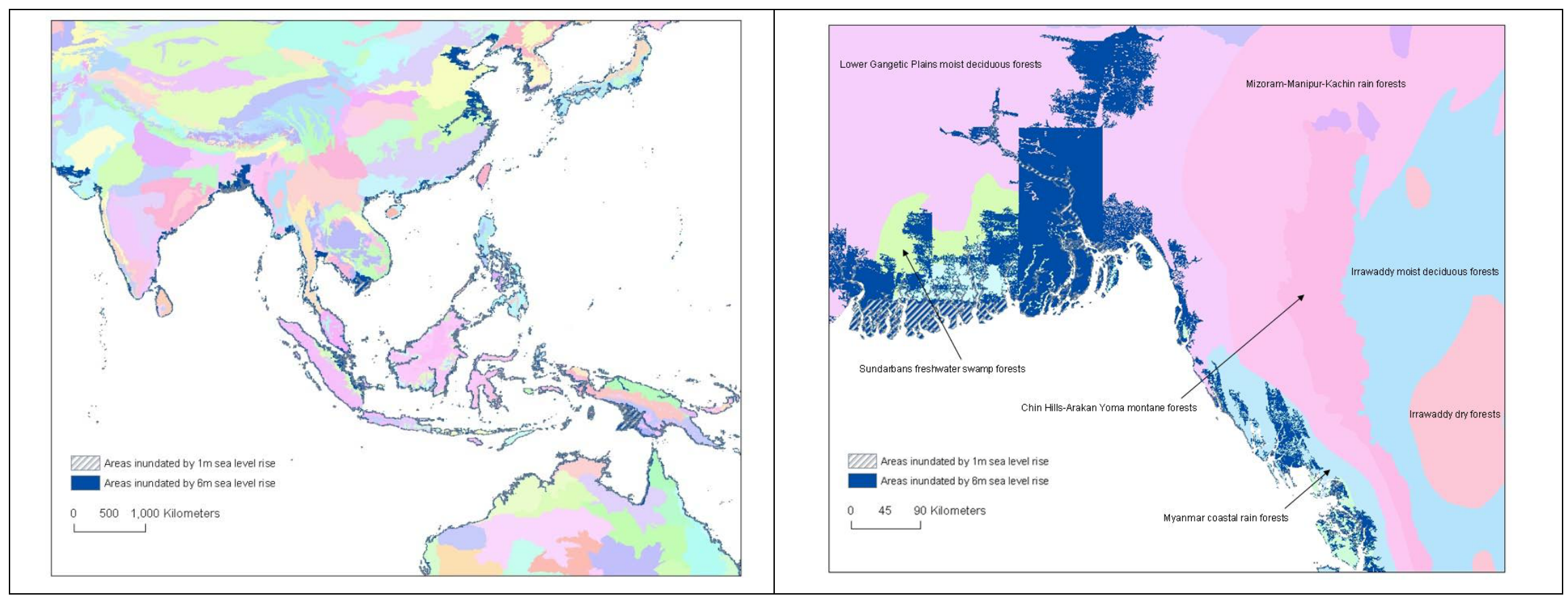




\section{Appendix}

Summary of projected effects of sea level rise on global ecoregions (Olson et al. 2001). Ecoregions for which no data on endemism were provided are excluded from this summary. Abbreviation: "end" = endemism.

\begin{tabular}{|c|c|c|c|c|c|c|c|c|c|c|c|}
\hline Continent or region & Ecoregion & Area $\left(\mathrm{km}^{2}\right)$ & $\begin{array}{l}\% \text { loss } \\
(6 \mathrm{~m})\end{array}$ & $\begin{array}{c}\% \text { loss } \\
(1 \mathrm{~m})\end{array}$ & Total end & Total strict end & Total near end & $\begin{array}{c}\text { Global model } \\
(6 \mathrm{~m})\end{array}$ & $\begin{array}{c}\text { Global model } \\
(1 \mathrm{~m})\end{array}$ & $\begin{array}{c}\text { Regional model } \\
(6 \mathrm{~m})\end{array}$ & $\begin{array}{c}\text { Regional model } \\
(1 \mathrm{~m})\end{array}$ \\
\hline \multirow[t]{21}{*}{ Africa } & Albany thickets & 17030 & 0.57 & 0.11 & 13 & 1 & 12 & 13.0 & 13.0 & 13.0 & \\
\hline & Angolan Miombo woodlands & 661412 & 0.00 & 0.00 & 36 & 5 & 31 & 36.0 & 36.0 & 36.0 & 36.0 \\
\hline & Angolan scarp savanna and woodlands & 74530 & 2.80 & 1.47 & 35 & 5 & 30 & 34.9 & 34.9 & 34.8 & 34.9 \\
\hline & Atlantic coastal desert & 40006 & 3.09 & 0.03 & 1 & 0 & 1 & 1.0 & 1.0 & 1.0 & 1.0 \\
\hline & Atlantic Equatorial coastal forests & 190072 & 4.80 & 3.64 & 47 & 6 & 41 & 46.7 & 46.8 & 46.5 & 46.7 \\
\hline & Central African mangroves & 30934 & 23.81 & 20.30 & 5 & 0 & 5 & 4.8 & 4.9 & 4.7 & 4.8 \\
\hline & Cross-Sanaga-Bioko coastal forests & 52211 & 4.28 & 3.81 & 52 & 3 & 49 & 51.7 & 51.8 & 51.5 & 51.6 \\
\hline & East African mangroves & 16110 & 41.35 & 20.58 & 1 & 0 & 1 & 0.9 & 1.0 & 0.9 & 1.0 \\
\hline & Eritrean coastal desert & 4627 & 19.02 & 1.17 & 2 & 0 & 2 & 1.9 & 2.0 & 1.9 & 2.0 \\
\hline & Ethiopian xeric grasslands and shrublands & 153342 & 1.62 & 0.32 & 33 & 2 & 31 & 32.9 & 33.0 & 32.9 & 33.0 \\
\hline & Hobyo grasslands and shrublands & 25600 & 0.18 & 0.02 & 18 & 5 & 13 & 18.0 & 18.0 & 18.0 & 18.0 \\
\hline & Kaokoveld desert & 45868 & 1.37 & 0.43 & 38 & 6 & 32 & 37.9 & 38.0 & 37.9 & 38.0 \\
\hline & Knysna-Amatole montane forests & 2993 & 0.80 & 0.03 & 22 & 5 & 17 & 22.0 & 22.0 & 22.0 & 22.0 \\
\hline & KwaZulu-Cape coastal forest mosaic & 17844 & 1.08 & 0.47 & 31 & 1 & 30 & 31.0 & 31.0 & 30.9 & 31.0 \\
\hline & Lowland fynbos and renosterveld & 32865 & 1.71 & 0.27 & 53 & 4 & 49 & 52.9 & 53.0 & 52.9 & 53.0 \\
\hline & Maputaland coastal forest mosaic & 30232 & 3.24 & 0.36 & 30 & 2 & 28 & 29.9 & 30.0 & 29.8 & 30.0 \\
\hline & Maputaland-Pondoland bushland and thickets & 19534 & 0.02 & 0.01 & 22 & 1 & 21 & 22.0 & 22.0 & 22.0 & 22.0 \\
\hline & Montane fynbos and renosterveld & 45849 & 0.10 & 0.07 & 70 & 12 & 58 & 70.0 & 70.0 & 70.0 & 70.0 \\
\hline & Namib desert & 81028 & 1.14 & 0.37 & 44 & 3 & 41 & 43.9 & 44.0 & 43.9 & 44.0 \\
\hline & Niger Delta swamp forests & 14479 & 0.61 & 0.28 & 5 & 0 & 5 & 5.0 & 5.0 & 5.0 & 5.0 \\
\hline & Nigerian lowland forests & 67469 & 0.77 & 0.24 & 10 & 2 & 8 & 10.0 & 10.0 & 10.0 & 10.0 \\
\hline
\end{tabular}




\begin{tabular}{|c|c|c|c|c|c|c|c|c|c|c|c|}
\hline & Nile Delta flooded savanna & 51149 & 10.71 & 0.35 & 1 & 0 & 1 & 1.0 & 1.0 & 1.0 & 1.0 \\
\hline & North Saharan steppe and woodlands & 1679755 & 0.19 & 0.08 & 6 & 0 & 6 & 6.0 & 6.0 & 6.0 & 6.0 \\
\hline & Northern Zanzibar-Inhambane coastal forest mosaic & 112892 & 6.12 & 3.59 & 128 & 27 & 101 & 127.0 & 127.4 & 126.4 & 127.1 \\
\hline & Saharan halophytics & 54146 & 0.62 & 0.06 & 1 & 0 & 1 & 1.0 & 1.0 & 1.0 & 1.0 \\
\hline & Sahelian Acacia savanna & 3060463 & 0.03 & 0.01 & 42 & 10 & 32 & 42.0 & 42.0 & 42.0 & 42.0 \\
\hline & Somali Acacia-Commiphora bushlands and thickets & 1056351 & 0.08 & 0.05 & 133 & 28 & 105 & 133.0 & 133.0 & 133.0 & 133.0 \\
\hline & Somali montane xeric woodlands & 62740 & 0.53 & 0.11 & 28 & 4 & 24 & 28.0 & 28.0 & 28.0 & 28.0 \\
\hline & Southern Africa mangroves & 1001 & 10.49 & 2.20 & 1 & 0 & 1 & 1.0 & 1.0 & 1.0 & 1.0 \\
\hline & Southern Zanzibar-Inhambane coastal forest mosaic & 147227 & 5.03 & 2.02 & 48 & 7 & 41 & 47.7 & 47.9 & 47.5 & 47.8 \\
\hline & Succulent Karoo & 102954 & 0.29 & 0.11 & 63 & 9 & 54 & 63.0 & 63.0 & 63.0 & 63.0 \\
\hline & West Sudanian savanna & 1642134 & 0.14 & 0.08 & 51 & 10 & 41 & 51.0 & 51.0 & 51.0 & 51.0 \\
\hline & Western Congolian forest-savanna mosaic & 414381 & 0.54 & 0.11 & 23 & 3 & 20 & 23.0 & 23.0 & 23.0 & 23.0 \\
\hline & Zambezian coastal flooded savanna & 19603 & 21.87 & 0.14 & 4 & 1 & 3 & 3.9 & 4.0 & 3.8 & 4.0 \\
\hline \multirow[t]{4}{*}{ Africa/Europe } & Mediterranean acacia-argania dry woodlands and succulent thickets & 100308 & 0.38 & 0.15 & 26 & 6 & 20 & 26.0 & 26.0 & 26.0 & 26.0 \\
\hline & Mediterranean conifer and mixed forests & 23134 & 0.93 & 0.70 & 3 & 1 & 2 & 3.0 & 3.0 & 3.0 & 3.0 \\
\hline & Mediterranean dry woodlands and steppe & 292727 & 1.01 & 0.43 & 3 & 0 & 3 & 3.0 & 3.0 & 3.0 & 3.0 \\
\hline & Mediterranean woodlands and forests & 359213 & 1.43 & 0.69 & 18 & 3 & 15 & 18.0 & 18.0 & 18.0 & 18.0 \\
\hline \multirow[t]{2}{*}{ Antarctica } & Marielandia Antarctic tundra & 1149005 & 0.51 & 0.12 & 0 & 0 & 0 & 0.0 & 0.0 & 0.0 & 0.0 \\
\hline & Maudlandia Antarctic desert & 2119791 & 0.39 & 0.10 & 0 & 0 & 0 & 0.0 & 0.0 & 0.0 & 0.0 \\
\hline \multirow[t]{7}{*}{ Asia } & Aegean and Western Turkey sclerophyllous and mixed forests & 133827 & 3.35 & 1.84 & 13 & 5 & 8 & 12.9 & 13.0 & 12.9 & 13.0 \\
\hline & Anatolian conifer and deciduous mixed forests & 86550 & 0.48 & 0.39 & 0 & 0 & 0 & 0.0 & 0.0 & 0.0 & 0.0 \\
\hline & Arabian Desert and East Sahero-Arabian xeric shrublands & 1855231 & 0.12 & 0.02 & 3 & 0 & 3 & 3.0 & 3.0 & 3.0 & 3.0 \\
\hline & Arabian Peninsula coastal fog desert & 83264 & 5.45 & 0.76 & 5 & 0 & 5 & 5.0 & 5.0 & 4.9 & 5.0 \\
\hline & Baluchistan xeric woodlands & 289415 & 0.09 & 0.02 & 15 & 2 & 13 & 15.0 & 15.0 & 15.0 & 15.0 \\
\hline & Bohai Sea saline meadow & 11580 & 41.19 & 1.47 & 0 & 0 & 0 & 0.0 & 0.0 & 0.0 & 0.0 \\
\hline & Cardamom Mountains rain forests & 44307 & 0.85 & 0.27 & 18 & 6 & 12 & 18.0 & 18.0 & 18.0 & 18.0 \\
\hline
\end{tabular}




\begin{tabular}{|c|c|c|c|c|c|c|c|c|c|c|}
\hline Caucasus mixed forests & 170708 & 0.01 & 0.00 & 12 & 5 & 7 & 12.0 & 12.0 & 12.0 & 12.0 \\
\hline Central Deccan Plateau dry deciduous forests & 240677 & 0.65 & 0.16 & 4 & 1 & 3 & 4.0 & 4.0 & 4.0 & 4.0 \\
\hline Central Indochina dry forests & 320854 & 0.17 & 0.00 & 14 & 3 & 11 & 14.0 & 14.0 & 14.0 & 14.0 \\
\hline Central Korean deciduous forests & 104749 & 4.77 & 0.92 & 1 & 0 & 1 & 1.0 & 1.0 & 1.0 & 1.0 \\
\hline Changjiang Plain evergreen forests & 438855 & 6.52 & 0.51 & 10 & 0 & 10 & 9.9 & 10.0 & 9.9 & 10.0 \\
\hline Chao Phraya freshwater swamp forests & 39102 & 20.32 & 0.06 & 11 & 2 & 9 & 10.7 & 11.0 & 10.5 & 11.0 \\
\hline Chao Phraya lowland moist deciduous forests & 20517 & 3.16 & 0.03 & 1 & 0 & 1 & 1.0 & 1.0 & 1.0 & 1.0 \\
\hline Cherskii-Kolyma mountain tundra & 557883 & 0.01 & 0.01 & 0 & 0 & 0 & 0.0 & 0.0 & 0.0 & 0.0 \\
\hline Chukchi Peninsula tundra & 298986 & 1.40 & 0.65 & 0 & 0 & 0 & 0.0 & 0.0 & 0.0 & 0.0 \\
\hline Deccan thorn scrub forests & 340967 & 1.32 & 0.43 & 15 & 3 & 12 & 15.0 & 15.0 & 15.0 & 15.0 \\
\hline East Deccan dry-evergreen forests & 25583 & 25.24 & 8.38 & 3 & 0 & 3 & 2.9 & 3.0 & 2.8 & 2.9 \\
\hline East Siberian taiga & 3908414 & 0.02 & 0.02 & 0 & 0 & 0 & 0.0 & 0.0 & 0.0 & 0.0 \\
\hline Eastern highlands moist deciduous forests & 341677 & 0.92 & 0.33 & 6 & 2 & 4 & 6.0 & 6.0 & 6.0 & 6.0 \\
\hline Goadavari-Krishna mangroves & 6997 & 70.60 & 37.20 & 11 & 3 & 8 & 9.5 & 10.4 & 8.6 & 10.0 \\
\hline Guinean forest-savanna mosaic & 675071 & 0.51 & 0.09 & 47 & 6 & 41 & 47.0 & 47.0 & 47.0 & 47.0 \\
\hline Guinean mangroves & 23675 & 26.99 & 4.68 & 1 & 0 & 1 & 1.0 & 1.0 & 0.9 & 1.0 \\
\hline Gulf of Oman desert and semi-desert & 62610 & 3.33 & 0.59 & 2 & 0 & 2 & 2.0 & 2.0 & 2.0 & 2.0 \\
\hline Huang He Plain mixed forests & 435176 & 5.21 & 0.04 & 2 & 0 & 2 & 2.0 & 2.0 & 2.0 & 2.0 \\
\hline Indochina mangroves & 26948 & 80.00 & 57.75 & 8 & 2 & 6 & 6.6 & 7.2 & 5.8 & 6.7 \\
\hline Indus River Delta-Arabian Sea mangroves & 5802 & 45.43 & 8.10 & 1 & 0 & 1 & 0.9 & 1.0 & 0.9 & 1.0 \\
\hline Jian Nan subtropical evergreen forests & 665300 & 0.45 & 0.24 & 33 & 7 & 26 & 33.0 & 33.0 & 33.0 & 33.0 \\
\hline Kamchatka Mountain tundra and forest tundra & 119518 & 0.76 & 0.15 & 0 & 0 & 0 & 0.0 & 0.0 & 0.0 & 0.0 \\
\hline Kamchatka-Kurile meadows and sparse forests & 146771 & 3.83 & 1.07 & 0 & 0 & 0 & 0.0 & 0.0 & 0.0 & 0.0 \\
\hline Khathiar-Gir dry deciduous forests & 267763 & 0.47 & 0.03 & 2 & 0 & 2 & 2.0 & 2.0 & 2.0 & 2.0 \\
\hline Lesser Sundas deciduous forests & 39542 & 3.82 & 2.65 & 46 & 12 & 34 & 45.8 & 45.8 & 45.6 & 45.8 \\
\hline Lower Gangetic Plains moist deciduous forests & 254698 & 11.66 & 0.30 & 10 & 1 & 9 & 9.8 & 10.0 & 9.8 & 10.0 \\
\hline
\end{tabular}




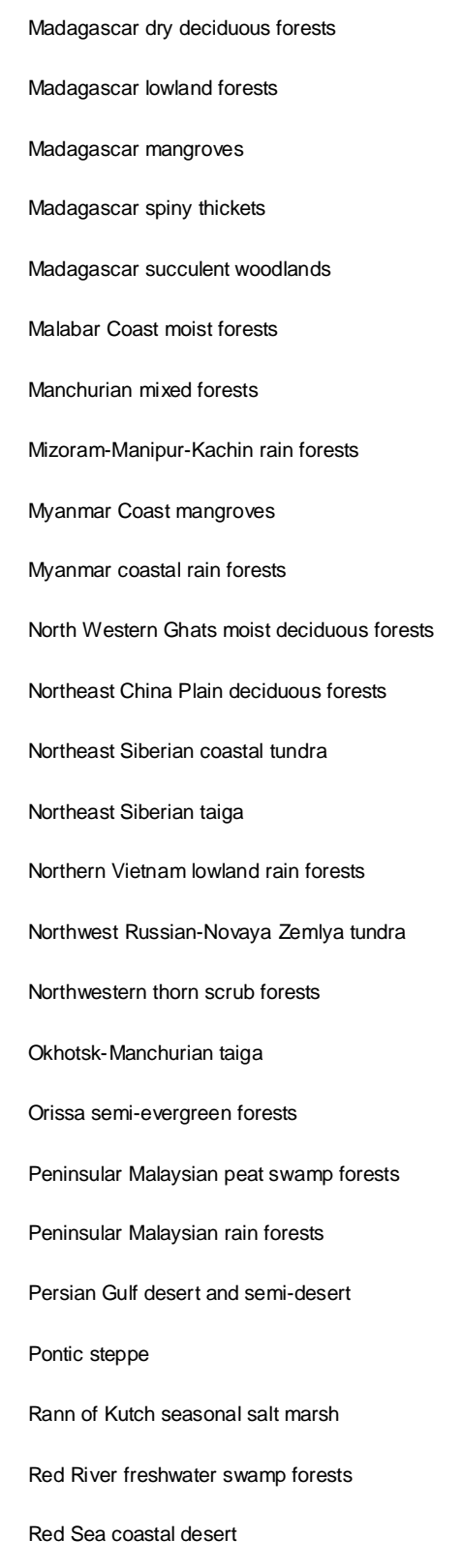

\begin{tabular}{|c|c|c|c|c|c|c|c|c|c|}
\hline 152452 & 1.08 & 0.10 & 123 & 26 & 97 & 122.8 & 123.0 & 122.7 & 123.0 \\
\hline 112319 & 1.57 & 0.23 & 313 & 83 & 230 & 312.4 & 312.9 & 312.0 & 312.9 \\
\hline 5192 & 6.70 & 1.16 & 7 & 0 & 7 & 6.9 & 7.0 & 6.9 & 7.0 \\
\hline 43477 & 0.72 & 0.32 & 77 & 17 & 60 & 76.9 & 77.0 & 76.9 & 77.0 \\
\hline 79907 & 0.41 & 0.01 & 31 & 4 & 27 & 31.0 & 31.0 & 31.0 & 31.0 \\
\hline 35544 & 15.50 & 4.14 & 28 & 5 & 23 & 27.4 & 27.9 & 27.1 & 27.8 \\
\hline 505177 & 0.36 & 0.05 & 1 & 0 & 1 & 1.0 & 1.0 & 1.0 & 1.0 \\
\hline 135864 & 0.00 & 0.00 & 23 & 4 & 19 & 23.0 & 23.0 & 23.0 & 23.0 \\
\hline 21410 & 26.36 & 4.52 & 2 & 0 & 2 & 1.9 & 2.0 & 1.9 & 2.0 \\
\hline 66711 & 10.40 & 0.60 & 16 & 3 & 13 & 15.8 & 16.0 & 15.7 & 16.0 \\
\hline 48357 & 0.16 & 0.03 & 19 & 1 & 18 & 19.0 & 19.0 & 19.0 & 19.0 \\
\hline 232977 & 4.00 & 0.33 & 6 & 3 & 3 & 6.0 & 6.0 & 6.0 & 6.0 \\
\hline 223112 & 9.52 & 1.25 & 0 & 0 & 0 & 0.0 & 0.0 & 0.0 & 0.0 \\
\hline 1128358 & 0.34 & 0.06 & 0 & 0 & 0 & 0.0 & 0.0 & 0.0 & 0.0 \\
\hline 22695 & 4.35 & 0.36 & 8 & 1 & 7 & 8.0 & 8.0 & 7.9 & 8.0 \\
\hline 284890 & 2.40 & 0.76 & 0 & 0 & 0 & 0.0 & 0.0 & 0.0 & 0.0 \\
\hline 489387 & 2.66 & 0.11 & 17 & 4 & 13 & 16.9 & 17.0 & 16.9 & 17.0 \\
\hline 402820 & 0.86 & 0.19 & 0 & 0 & 0 & 0.0 & 0.0 & 0.0 & 0.0 \\
\hline 22366 & 22.45 & 10.07 & 6 & 0 & 6 & 5.8 & 5.9 & 5.7 & 5.9 \\
\hline 3669 & 6.98 & 74.84 & 1 & 0 & 1 & 1.0 & 0.8 & 1.0 & 0.8 \\
\hline 125637 & 6.00 & 0.30 & 32 & 7 & 25 & 31.8 & 32.0 & 31.6 & 32.0 \\
\hline 72860 & 7.20 & 0.00 & 0 & 0 & 0 & 0.0 & 0.0 & 0.0 & 0.0 \\
\hline 996270 & 0.89 & 0.12 & 6 & 2 & 4 & 6.0 & 6.0 & 6.0 & 6.0 \\
\hline 28072 & 61.15 & 1.02 & 4 & 0 & 4 & 3.6 & 4.0 & 3.5 & 4.0 \\
\hline 10739 & 40.53 & 4.63 & 0 & 0 & 0 & 0.0 & 0.0 & 0.0 & 0.0 \\
\hline 59493 & 1.80 & 0.32 & 2 & 1 & 1 & 2.0 & 2.0 & 2.0 & 2.0 \\
\hline
\end{tabular}


Red Sea Nubo-Sindian tropical desert and semi-desert

South China-Vietnam subtropical evergreen forests

South Iran Nubo-Sindian desert and semi-desert

South Sakhalin-Kurile mixed forests

South Taiwan monsoon rain forests

Southeastern Indochina dry evergreen forests

Southern Korea evergreen forests

Southern Vietnam lowland dry forests

Southwestern Arabian foothills savanna

Sri Lanka dry-zone dry evergreen forests

Sri Lanka lowland rain forests

Suiphun-Khanka meadows and forest meadows

Sundarbans freshwater swamp forests

Sundarbans mangroves

Taimyr-Central Siberian tundra

Taiwan subtropical evergreen forests

Tigris-Euphrates alluvial salt marsh

Tonle Sap freshwater swamp forests

Tonle Sap-Mekong peat swamp forests

Ussuri broadleaf and mixed forests

West Siberian taiga

Yamal-Gydan tundra

Yellow Sea saline meadow

Euxine-Colchic broadleaf forests

Crimean Submediterranean forest complex

Southern Anatolian montane conifer and deciduous forests

\begin{tabular}{|c|c|c|c|c|c|c|c|c|c|}
\hline 653010 & 0.26 & 0.03 & 1 & 0 & 1 & 1.0 & 1.0 & 1.0 & 1.0 \\
\hline 224929 & 2.48 & 0.41 & 33 & 6 & 27 & 32.9 & 33.0 & 32.9 & 33.0 \\
\hline 352341 & 3.21 & 0.37 & 5 & 0 & 5 & 5.0 & 5.0 & 5.0 & 5.0 \\
\hline 12556 & 1.45 & 0.63 & 0 & 0 & 0 & 0.0 & 0.0 & 0.0 & 0.0 \\
\hline 2584 & 8.05 & 2.79 & 26 & 0 & 26 & 25.7 & 25.9 & 25.6 & 25.9 \\
\hline 124533 & 1.08 & 0.04 & 7 & 0 & 7 & 7.0 & 7.0 & 7.0 & 7.0 \\
\hline 14720 & 9.49 & 4.12 & 2 & 1 & 1 & 2.0 & 2.0 & 2.0 & 2.0 \\
\hline 35082 & 2.86 & 1.05 & 10 & 1 & 9 & 10.0 & 10.0 & 9.9 & 10.0 \\
\hline 275077 & 0.00 & 0.00 & 8 & 0 & 8 & 8.0 & 8.0 & 8.0 & 8.0 \\
\hline 48526 & 5.72 & 1.62 & 51 & 10 & 41 & 50.6 & 50.9 & 50.4 & 50.8 \\
\hline 12587 & 3.14 & 0.75 & 59 & 7 & 52 & 58.8 & 58.9 & 58.6 & 58.9 \\
\hline 33797 & 0.32 & 0.04 & 0 & 0 & 0 & 0.0 & 0.0 & 0.0 & 0.0 \\
\hline 14607 & 41.95 & 1.20 & 2 & 0 & 2 & 1.9 & 2.0 & 1.8 & 2.0 \\
\hline 20455 & 72.71 & 23.84 & 3 & 0 & 3 & 2.6 & 2.9 & 2.5 & 2.9 \\
\hline 956921 & 2.35 & 0.85 & 0 & 0 & 0 & 0.0 & 0.0 & 0.0 & 0.0 \\
\hline 33528 & 4.57 & 1.42 & 40 & 6 & 34 & 39.8 & 39.9 & 39.7 & 39.9 \\
\hline 35666 & 1.71 & 0.68 & 1 & 0 & 1 & 1.0 & 1.0 & 1.0 & 1.0 \\
\hline 26095 & 44.33 & 21.16 & 6 & 1 & 5 & 5.6 & 5.8 & 5.3 & 5.7 \\
\hline 29408 & 58.77 & 22.93 & 1 & 0 & 1 & 0.9 & 1.0 & 0.8 & 0.9 \\
\hline 197864 & 0.16 & 0.05 & 0 & 0 & 0 & 0.0 & 0.0 & 0.0 & 0.0 \\
\hline 1674101 & 0.27 & 0.01 & 0 & 0 & 0 & 0.0 & 0.0 & 0.0 & 0.0 \\
\hline 413018 & 4.52 & 1.16 & 0 & 0 & 0 & 0.0 & 0.0 & 0.0 & 0.0 \\
\hline 5321 & 53.58 & 1.82 & 1 & 0 & 1 & 0.9 & 1.0 & 0.9 & 1.0 \\
\hline 74596 & 1.44 & 0.44 & 2 & 0 & 2 & 2.0 & 2.0 & 2.0 & 2.0 \\
\hline 30240 & 0.06 & 0.02 & 0 & 0 & 0 & 0.0 & 0.0 & 0.0 & 0.0 \\
\hline 76674 & 0.07 & 0.05 & 2 & 0 & 2 & 2.0 & 2.0 & 2.0 & 2.0 \\
\hline
\end{tabular}




\begin{tabular}{|c|c|c|c|c|c|c|c|c|c|c|c|}
\hline \multirow[t]{6}{*}{ Asia/ Europe/North America } & Arctic coastal tundra & 98272 & 13.56 & 7.55 & 0 & 0 & 0 & 0.0 & 0.0 & 0.0 & 0.0 \\
\hline & Arctic desert & 161756 & 2.44 & 1.80 & 0 & 0 & 0 & 0.0 & 0.0 & 0.0 & 0.0 \\
\hline & Arctic foothills tundra & 129417 & 1.27 & 0.92 & 0 & 0 & 0 & 0.0 & 0.0 & 0.0 & 0.0 \\
\hline & High Arctic tundra & 464713 & 6.34 & 4.08 & 1 & 0 & 1 & 1.0 & 1.0 & 1.0 & 1.0 \\
\hline & Low Arctic tundra & 798421 & 3.64 & 1.95 & 0 & 0 & 0 & 0.0 & 0.0 & 0.0 & 0.0 \\
\hline & Middle Arctic tundra & 1035068 & 5.43 & 3.13 & 0 & 0 & 0 & 0.0 & 0.0 & 0.0 & 0.0 \\
\hline \multirow[t]{2}{*}{ Asia/North America } & Beringia lowland tundra & 151223 & 22.82 & 9.23 & 3 & 0 & 3 & 2.9 & 3.0 & 2.9 & 3.0 \\
\hline & Beringia upland tundra & 97577 & 1.91 & 0.80 & 3 & 0 & 3 & 3.0 & 3.0 & 3.0 & 3.0 \\
\hline \multirow[t]{18}{*}{ Australia } & Arnhem Land tropical savanna & 158466 & 13.06 & 8.39 & 49 & 11 & 38 & 48.2 & 48.5 & 47.7 & 48.2 \\
\hline & Biak-Numfoor rain forests & 2827 & 23.03 & 15.35 & 28 & 10 & 18 & 27.1 & 27.4 & 26.6 & 27.1 \\
\hline & Brigalow tropical savanna & 343173 & 0.98 & 0.63 & 39 & 7 & 32 & 39.0 & 39.0 & 38.9 & 39.0 \\
\hline & Cape York Peninsula tropical savanna & 116646 & 9.67 & 5.91 & 72 & 17 & 55 & 71.1 & 71.5 & 70.6 & 71.1 \\
\hline & Carnarvon xeric shrublands & 90736 & 4.83 & 2.33 & 38 & 6 & 32 & 37.8 & 37.9 & 37.7 & 37.9 \\
\hline & Carpentaria tropical savanna & 360428 & 4.30 & 2.14 & 21 & 4 & 17 & 20.9 & 20.9 & 20.8 & 20.9 \\
\hline & Coolgardie woodlands & 137666 & 0.97 & 0.38 & 2 & 0 & 2 & 2.0 & 2.0 & 2.0 & 2.0 \\
\hline & Eastern Australian temperate forests & 222501 & 3.78 & 2.68 & 121 & 39 & 82 & 120.4 & 120.6 & 120.3 & 120.5 \\
\hline & Esperance mallee & 6526 & 66.66 & 50.37 & 21 & 4 & 17 & 18.3 & 19.3 & 17.8 & 18.9 \\
\hline & Eyre and York mallee & 61017 & 7.24 & 3.86 & 12 & 2 & 10 & 11.9 & 11.9 & 11.9 & 11.9 \\
\hline & Jarrah-Karri forest and shrublands & 10465 & 5.69 & 2.53 & 15 & 0 & 15 & 14.9 & 15.0 & 14.9 & 14.9 \\
\hline & Kimberly tropical savanna & 348683 & 3.68 & 2.27 & 106 & 31 & 75 & 105.5 & 105.7 & 105.2 & 105.5 \\
\hline & Mount Lofty woodlands & 23818 & 1.78 & 0.88 & 8 & 1 & 7 & 8.0 & 8.0 & 8.0 & 8.0 \\
\hline & Murray-Darling woodlands and mallee & 198388 & 0.04 & 0.01 & 12 & 1 & 11 & 12.0 & 12.0 & 12.0 & 12.0 \\
\hline & Naracoorte woodlands & 27579 & 5.28 & 2.49 & 4 & 0 & 4 & 4.0 & 4.0 & 4.0 & 4.0 \\
\hline & Nullarbor Plains xeric shrublands & 195721 & 0.59 & 0.24 & 4 & 1 & 3 & 4.0 & 4.0 & 4.0 & 4.0 \\
\hline & Pilbara shrublands & 179992 & 1.84 & 0.99 & 31 & 9 & 22 & 30.9 & 31.0 & 30.9 & 30.9 \\
\hline & Queensland tropical rain forests & 32740 & 6.20 & 4.14 & 123 & 31 & 92 & 122.0 & 122.4 & 121.4 & 122.0 \\
\hline
\end{tabular}


Southeast Australia temperate forests

Southwest Australia savanna

Southwest Australia woodlands

Tasmanian Central Highland forests

Tasmanian temperate forests

Tasmanian temperate rain forests

Tirari-Sturt stony desert

Victoria Plains tropical savanna

Atlantic mixed forests

Balkan mixed forests

Baltic mixed forests

Caledon conifer forests

Cantabrian mixed forests

Celtic broadleaf forests

Central European mixed forests

Crete Mediterranean forests

Cyprus Mediterranean forests

East European forest steppe

Eastern Mediterranean conifer-sclerophyllous-broadleaf forests

English Lowlands beech forests

Fiordland temperate forests

Iberian sclerophyllous and semi-deciduous forests

Illyrian deciduous forests

Italian sclerophyllous and semi-deciduous forests

Kola Peninsula tundra

North Atlantic moist mixed forests

\begin{tabular}{|c|c|c|c|c|c|c|c|c|c|}
\hline 272908 & 2.24 & 1.56 & 34 & 7 & 27 & 33.9 & 33.9 & 33.9 & 33.9 \\
\hline 169277 & 0.73 & 0.52 & 41 & 5 & 36 & 41.0 & 41.0 & 41.0 & 41.0 \\
\hline 46160 & 0.62 & 0.39 & 22 & 1 & 21 & 22.0 & 22.0 & 22.0 & 22.0 \\
\hline 18694 & 0.77 & 0.64 & 14 & 1 & 13 & 14.0 & 14.0 & 14.0 & 14.0 \\
\hline 18299 & 13.32 & 9.55 & 12 & 0 & 12 & 11.8 & 11.9 & 11.7 & 11.8 \\
\hline 31370 & 6.00 & 4.65 & 16 & 2 & 14 & 15.9 & 15.9 & 15.8 & 15.9 \\
\hline 377742 & 0.08 & 0.04 & 14 & 2 & 12 & 14.0 & 14.0 & 14.0 & 14.0 \\
\hline 226271 & 0.00 & 0.03 & 9 & 0 & 9 & 9.0 & 9.0 & 9.0 & 9.0 \\
\hline 399925 & 9.65 & 4.17 & 0 & 0 & 0 & 0.0 & 0.0 & 0.0 & 0.0 \\
\hline 224882 & 0.57 & 0.07 & 5 & 0 & 5 & 5.0 & 5.0 & 5.0 & 5.0 \\
\hline 116832 & 8.14 & 2.34 & 0 & 0 & 0 & 0.0 & 0.0 & 0.0 & 0.0 \\
\hline 22056 & 0.53 & 0.36 & 0 & 0 & 0 & 0.0 & 0.0 & 0.0 & 0.0 \\
\hline 79889 & 0.78 & 0.14 & 6 & 1 & 5 & 6.0 & 6.0 & 6.0 & 6.0 \\
\hline 209601 & 3.98 & 2.18 & 0 & 0 & 0 & 0.0 & 0.0 & 0.0 & 0.0 \\
\hline 732883 & 0.22 & 0.04 & 0 & 0 & 0 & 0.0 & 0.0 & 0.0 & 0.0 \\
\hline 8196 & 1.84 & 1.22 & 4 & 1 & 3 & 4.0 & 4.0 & 4.0 & 4.0 \\
\hline 9279 & 2.94 & 2.52 & 13 & 4 & 9 & 13.0 & 13.0 & 12.9 & 12.9 \\
\hline 728773 & 0.00 & 0.00 & 1 & 0 & 1 & 1.0 & 1.0 & 1.0 & 1.0 \\
\hline 144130 & 0.78 & 0.34 & 8 & 3 & 5 & 8.0 & 8.0 & 8.0 & 8.0 \\
\hline 45710 & 6.46 & 3.70 & 0 & 0 & 0 & 0.0 & 0.0 & 0.0 & 0.0 \\
\hline 11050 & 0.47 & 0.24 & 6 & 1 & 5 & 6.0 & 6.0 & 6.0 & 6.0 \\
\hline 298264 & 0.06 & 0.00 & 3 & 0 & 3 & 3.0 & 3.0 & 3.0 & 3.0 \\
\hline 40685 & 3.80 & 0.37 & 10 & 1 & 9 & 10.0 & 10.0 & 9.9 & 10.0 \\
\hline 102274 & 2.17 & 0.20 & 5 & 1 & 4 & 5.0 & 5.0 & 5.0 & 5.0 \\
\hline 58851 & 0.88 & 0.63 & 0 & 0 & 0 & 0.0 & 0.0 & 0.0 & 0.0 \\
\hline 38712 & 4.84 & 3.26 & 0 & 0 & 0 & 0.0 & 0.0 & 0.0 & 0.0 \\
\hline
\end{tabular}

The original publication is available at www.springerlink.com | DOI: 10.1007/s10531-010-9790-4 


\begin{tabular}{|c|c|c|c|c|c|c|c|c|c|c|c|}
\hline & Northeastern Spain and Southern France Mediterranean forests & 90952 & 3.73 & 1.81 & 6 & 2 & 4 & 6.0 & 6.0 & 6.0 & 6.0 \\
\hline & Po Basin mixed forests & 42415 & 15.46 & 3.94 & 1 & 0 & 1 & 1.0 & 1.0 & 1.0 & 1.0 \\
\hline & Sarmatic mixed forests & 848072 & 0.53 & 0.14 & 0 & 0 & 0 & 0.0 & 0.0 & 0.0 & 0.0 \\
\hline & Scandinavian and Russian taiga & 2161779 & 0.20 & 0.08 & 0 & 0 & 0 & 0.0 & 0.0 & 0.0 & 0.0 \\
\hline & Scandinavian coastal conifer forests & 19294 & 4.76 & 2.31 & 0 & 0 & 0 & 0.0 & 0.0 & 0.0 & 0.0 \\
\hline & Scandinavian Montane Birch forest and grasslands & 243800 & 0.59 & 0.44 & 0 & 0 & 0 & 0.0 & 0.0 & 0.0 & 0.0 \\
\hline & Southeastern Iberian shrubs and woodlands & 2868 & 3.14 & 1.01 & 1 & 0 & 1 & 1.0 & 1.0 & 1.0 & 1.0 \\
\hline & Southwest Iberian Mediterranean sclerophyllous and mixed forests & 71272 & 2.39 & 0.46 & 1 & 0 & 1 & 1.0 & 1.0 & 1.0 & 1.0 \\
\hline & Tyrrhenian-Adriatic Sclerophyllous and mixed forests & 85226 & 2.49 & 0.55 & 16 & 3 & 13 & 16.0 & 16.0 & 15.9 & 16.0 \\
\hline \multirow[t]{17}{*}{ Islands } & Admiralty Islands lowland rain forests & 2151 & 26.78 & 18.92 & 24 & 6 & 18 & 23.1 & 23.4 & 22.6 & 23.0 \\
\hline & Aldabra Island xeric scrub & 176 & 10.23 & 10.23 & 15 & 4 & 11 & 14.8 & 14.8 & 14.7 & 14.7 \\
\hline & Amsterdam and Saint-Paul Islands temperate grasslands & 65 & 3.08 & 3.08 & 0 & 0 & 0 & 0.0 & 0.0 & 0.0 & 0.0 \\
\hline & Andaman Islands rain forests & 5700 & 38.39 & 29.18 & 27 & 10 & 17 & 25.4 & 25.9 & 24.5 & 25.2 \\
\hline & Antipodes Subantarctic Islands tundra & 891 & 30.08 & 25.59 & 12 & 4 & 8 & 11.5 & 11.6 & 11.4 & 11.5 \\
\hline & Ascension scrub and grasslands & 88 & 18.18 & 12.50 & 0 & 0 & 0 & 0.0 & 0.0 & 0.0 & 0.0 \\
\hline & Azores temperate mixed forests & 2618 & 8.40 & 6.26 & 3 & 1 & 2 & 3.0 & 3.0 & 3.0 & 3.0 \\
\hline & Bahamian pine mosaic & 2092 & 68.83 & 13.67 & 19 & 3 & 16 & 16.4 & 18.7 & 15.9 & 18.6 \\
\hline & Banda Sea Islands moist deciduous forests & 7561 & 41.04 & 31.56 & 57 & 11 & 46 & 53.4 & 54.4 & 51.3 & 52.9 \\
\hline & Bermuda subtropical conifer forests & 43 & 37.21 & 30.23 & 1 & 0 & 1 & 0.9 & 1.0 & 0.9 & 0.9 \\
\hline & Borneo lowland rain forests & 428373 & 3.59 & 2.53 & 36 & 7 & 29 & 35.8 & 35.9 & 35.7 & 35.8 \\
\hline & Borneo montane rain forests & 115842 & 0.00 & 0.00 & 39 & 0 & 39 & 39.0 & 39.0 & 39.0 & 39.0 \\
\hline & Borneo peat swamp forests & 67737 & 21.13 & 15.28 & 6 & 0 & 6 & 5.8 & 5.9 & 5.7 & 5.8 \\
\hline & Buru rain forests & 8655 & 1.40 & 0.85 & 39 & 6 & 33 & 38.9 & 39.0 & 38.9 & 38.9 \\
\hline & Canary Islands dry woodlands and forests & 5004 & 0.06 & 0.06 & 25 & 7 & 18 & 25.0 & 25.0 & 25.0 & 25.0 \\
\hline & Cantebury-Otago tussock grasslands & 53604 & 0.88 & 0.33 & 5 & 0 & 5 & 5.0 & 5.0 & 5.0 & 5.0 \\
\hline & Cape Verde Islands dry forests & 4625 & 9.25 & 6.90 & 33 & 12 & 21 & 32.6 & 32.7 & 32.4 & 32.5 \\
\hline
\end{tabular}




\begin{tabular}{|c|c|c|c|c|c|c|c|c|c|c|}
\hline Carolines tropical moist forests & 578 & 21.28 & 17.65 & 28 & 6 & 22 & 27.2 & 27.3 & 26.7 & 26.9 \\
\hline Cayos Miskitos-San Andr@s Andrés and Providencia moist forests & 90 & 21.11 & 4.44 & 7 & 2 & 5 & 6.8 & 7.0 & 6.7 & 6.9 \\
\hline Central Polynesian tropical moist forests & 621 & 88.57 & 83.74 & 2 & 1 & 1 & 1.5 & 1.6 & 1.3 & 1.4 \\
\hline Chatham Island temperate forests & 807 & 38.17 & 32.09 & 0 & 0 & 0 & 0.0 & 0.0 & 0.0 & 0.0 \\
\hline Christmas and Cocos Islands tropical forests & 134 & 8.21 & 7.46 & 4 & 2 & 2 & 4.0 & 4.0 & 3.9 & 3.9 \\
\hline Clipperton Island shrub and grasslands & 5 & 100.00 & 100.00 & 0 & 0 & 0 & 0.0 & 0.0 & 0.0 & 0.0 \\
\hline Comoros forests & 2076 & 2.31 & 1.69 & 44 & 13 & 31 & 43.9 & 43.9 & 43.8 & 43.9 \\
\hline Cook Islands tropical moist forests & 206 & 28.64 & 23.79 & 12 & 4 & 8 & 11.5 & 11.6 & 11.2 & 11.4 \\
\hline Cuban cactus scrub & 3313 & 14.97 & 3.74 & 35 & 0 & 35 & 34.3 & 34.8 & 34.1 & 34.8 \\
\hline Cuban dry forests & 65845 & 8.88 & 0.86 & 41 & 0 & 41 & 40.5 & 41.0 & 40.2 & 40.9 \\
\hline Cuban moist forests & 21392 & 6.79 & 1.89 & 47 & 1 & 46 & 46.6 & 46.9 & 46.5 & 46.9 \\
\hline Cuban pine forests & 6427 & 7.76 & 1.09 & 38 & 0 & 38 & 37.6 & 37.9 & 37.4 & 37.9 \\
\hline Cuban wetlands & 5664 & 86.58 & 27.37 & 43 & 0 & 43 & 33.5 & 41.3 & 28.8 & 40.3 \\
\hline Eastern Java-Bali montane rain forests & 15861 & 0.18 & 0.14 & 19 & 0 & 19 & 19.0 & 19.0 & 19.0 & 19.0 \\
\hline Eastern Java-Bali rain forests & 54146 & 7.93 & 5.07 & 12 & 0 & 12 & 11.9 & 11.9 & 11.8 & 11.9 \\
\hline Eastern Micronesia tropical moist forests & 531 & 46.89 & 45.76 & 5 & 1 & 4 & 4.6 & 4.6 & 4.4 & 4.4 \\
\hline Enriquillo wetlands & 628 & 2.55 & 0.48 & 42 & 0 & 42 & 41.9 & 42.0 & 41.8 & 42.0 \\
\hline Faroe Islands boreal grasslands & 1456 & 3.50 & 2.13 & 0 & 0 & 0 & 0.0 & 0.0 & 0.0 & 0.0 \\
\hline Fernando de Noronha-Atol das Rocas moist forests & 17 & 52.94 & 47.06 & 3 & 1 & 2 & 2.7 & 2.8 & 2.6 & 2.6 \\
\hline Fiji tropical dry forests & 6923 & 11.14 & 7.67 & 2 & 0 & 2 & 2.0 & 2.0 & 2.0 & 2.0 \\
\hline Fiji tropical moist forests & 11654 & 9.56 & 7.53 & 44 & 10 & 34 & 43.5 & 43.6 & 43.1 & 43.3 \\
\hline Galapagos Galapagos Islands scrubland mosaic & 8005 & 7.66 & 4.51 & 71 & 18 & 53 & 70.3 & 70.6 & 69.9 & 70.4 \\
\hline Granitic Seychelles forests & 322 & 19.25 & 14.29 & 38 & 10 & 28 & 37.0 & 37.3 & 36.4 & 36.9 \\
\hline Greater Negros-Panay rain forests & 35102 & 5.41 & 1.65 & 111 & 26 & 85 & 110.2 & 110.8 & 109.8 & 110.6 \\
\hline Halmahera rain forests & 26875 & 5.91 & 3.86 & 64 & 13 & 51 & 63.5 & 63.7 & 63.2 & 63.5 \\
\hline Hawaii tropical dry forests & 6658 & 1.89 & 0.50 & 24 & 0 & 24 & 23.9 & 24.0 & 23.9 & 24.0 \\
\hline
\end{tabular}


Hawaii tropical low shrublands

Hawaii tropical moist forests

Hispaniolan dry forests

Hispaniolan moist forests

Hokkaido deciduous forests

Hokkaido montane conifer forests

Honshu alpine conifer forests

Huon Peninsula montane rain forests

Iceland boreal birch forests and alpine tundra

Ile Europa and Bassas da India xeric scrub

Islas Revillagigedo dry forests

Jamaican dry forests

Jamaican moist forests

Juan Fernández Islands temperate forests

Kermadec Islands subtropical moist forests

Leeward Islands moist forests

Lesser Antillean dry forests

Lord Howe Island subtropical forests

Louisiade Archipelago rain forests

Luzon rain forests

Maldives-Lakshadweep-Chagos Archipelago tropical moist forests

Marianas tropical dry forests

Marquesas tropical moist forests

Mascarene forests

Mentawai Islands rain forests

Mindanao-Eastern Visayas rain forests

\begin{tabular}{|c|c|c|c|c|c|c|c|c|c|}
\hline 1532 & 10.05 & 2.55 & 13 & 0 & 13 & 12.8 & 13.0 & 12.7 & 12.9 \\
\hline 6735 & 1.02 & 0.40 & 36 & 5 & 31 & 36.0 & 36.0 & 35.9 & 36.0 \\
\hline 15527 & 6.23 & 2.45 & 50 & 0 & 50 & 49.6 & 49.8 & 49.4 & 49.8 \\
\hline 46006 & 1.48 & 0.19 & 62 & 5 & 57 & 61.9 & 62.0 & 61.8 & 62.0 \\
\hline 25613 & 3.82 & 0.52 & 0 & 0 & 0 & 0.0 & 0.0 & 0.0 & 0.0 \\
\hline 45823 & 1.73 & 0.16 & 0 & 0 & 0 & 0.0 & 0.0 & 0.0 & 0.0 \\
\hline 11509 & 0.85 & 0.46 & 7 & 0 & 7 & 7.0 & 7.0 & 7.0 & 7.0 \\
\hline 16574 & 1.63 & 1.16 & 23 & 1 & 22 & 23.0 & 23.0 & 22.9 & 22.9 \\
\hline 91614 & 1.92 & 0.59 & 0 & 0 & 0 & 0.0 & 0.0 & 0.0 & 0.0 \\
\hline 3223 & 26.99 & 14.74 & 0 & 0 & 0 & 0.0 & 0.0 & 0.0 & 0.0 \\
\hline 218 & 73.39 & 73.39 & 11 & 3 & 8 & 9.3 & 9.3 & 8.5 & 8.5 \\
\hline 2345 & 4.01 & 0.38 & 51 & 0 & 51 & 50.7 & 51.0 & 50.6 & 51.0 \\
\hline 8334 & 0.44 & 0.12 & 56 & 2 & 54 & 56.0 & 56.0 & 56.0 & 56.0 \\
\hline 146 & 34.25 & 31.51 & 8 & 4 & 4 & 7.6 & 7.6 & 7.5 & 7.6 \\
\hline 35 & 5.71 & 5.71 & 0 & 0 & 0 & 0.0 & 0.0 & 0.0 & 0.0 \\
\hline 998 & 14.13 & 13.13 & 23 & 1 & 22 & 22.6 & 22.6 & 22.3 & 22.4 \\
\hline 144 & 65.97 & 65.28 & 14 & 0 & 14 & 12.2 & 12.3 & 11.3 & 11.3 \\
\hline 18 & 61.11 & 55.56 & 4 & 1 & 3 & 3.6 & 3.6 & 3.5 & 3.5 \\
\hline 1625 & 43.26 & 35.38 & 12 & 2 & 10 & 11.2 & 11.4 & 10.7 & 11.0 \\
\hline 95382 & 3.07 & 0.70 & 132 & 16 & 116 & 131.5 & 131.9 & 131.2 & 131.8 \\
\hline 297 & 22.56 & 21.89 & 0 & 0 & 0 & 0.0 & 0.0 & 0.0 & 0.0 \\
\hline 1039 & 12.61 & 0.48 & 17 & 3 & 14 & 16.7 & 17.0 & 16.6 & 17.0 \\
\hline 1083 & 17.54 & 13.11 & 19 & 8 & 11 & 18.6 & 18.7 & 18.3 & 18.5 \\
\hline 4932 & 1.26 & 0.81 & 37 & 13 & 24 & 36.9 & 37.0 & 36.9 & 36.9 \\
\hline 6517 & 16.39 & 11.92 & 28 & 8 & 20 & 27.4 & 27.6 & 27.0 & 27.3 \\
\hline 105386 & 3.43 & 1.00 & 129 & 9 & 120 & 128.4 & 128.8 & 128.1 & 128.7 \\
\hline
\end{tabular}




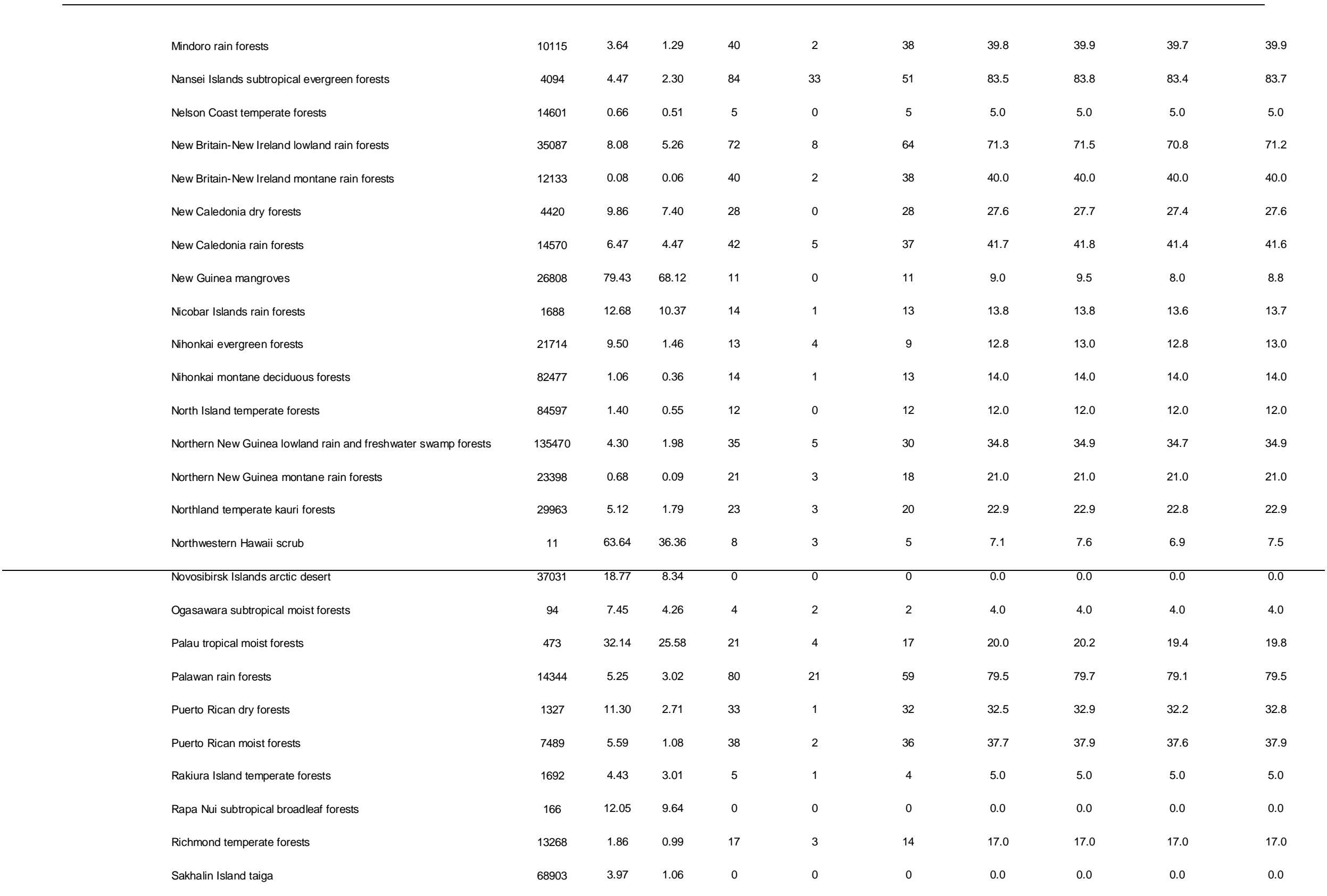




\begin{tabular}{|c|c|c|c|c|c|c|c|c|c|c|}
\hline Samoan tropical moist forests & 3110 & 9.23 & 6.95 & 25 & 6 & 19 & 24.7 & 24.8 & 24.5 & 24.6 \\
\hline San Félix-San Ambrosio Islands temperate forests & 6 & 16.67 & 16.67 & 0 & 0 & 0 & 0.0 & 0.0 & 0.0 & 0.0 \\
\hline Scotia Sea Islands tundra & 8474 & 4.39 & 2.38 & 3 & 1 & 2 & 3.0 & 3.0 & 3.0 & 3.0 \\
\hline Seram rain forests & 19455 & 4.67 & 3.10 & 54 & 12 & 42 & 53.7 & 53.8 & 53.5 & 53.7 \\
\hline Society Islands tropical moist forests & 1611 & 7.01 & 5.09 & 11 & 2 & 9 & 10.9 & 10.9 & 10.8 & 10.9 \\
\hline Socotra Island xeric shrublands & 3799 & 3.69 & 1.40 & 48 & 18 & 30 & 47.8 & 47.9 & 47.6 & 47.9 \\
\hline Solomon Islands rain forests & 35902 & 9.94 & 6.97 & 159 & 45 & 114 & 157.0 & 157.6 & 155.7 & 156.7 \\
\hline South China Sea Islands & 35 & 2.86 & 2.86 & 0 & 0 & 0 & 0.0 & 0.0 & 0.0 & 0.0 \\
\hline South Island montane grasslands & 40009 & 0.03 & 0.02 & 7 & 1 & 6 & 7.0 & 7.0 & 7.0 & 7.0 \\
\hline South Island temperate forests & 11706 & 1.41 & 0.11 & 3 & 0 & 3 & 3.0 & 3.0 & 3.0 & 3.0 \\
\hline Southeastern Papuan rain forests & 77531 & 3.80 & 2.42 & 72 & 4 & 68 & 71.7 & 71.8 & 71.4 & 71.6 \\
\hline Southern Indian Ocean Islands tundra & 8142 & 19.58 & 16.76 & 0 & 0 & 0 & 0.0 & 0.0 & 0.0 & 0.0 \\
\hline Southern New Guinea freshwater swamp forests & 100189 & 40.87 & 32.47 & 17 & 0 & 17 & 15.9 & 16.2 & 15.3 & 15.7 \\
\hline Southern New Guinea lowland rain forests & 123094 & 29.44 & 23.96 & 18 & 0 & 18 & 17.2 & 17.4 & 16.8 & 17.0 \\
\hline Southwest Borneo freshwater swamp forests & 36821 & 25.85 & 16.88 & 1 & 0 & 1 & 1.0 & 1.0 & 0.9 & 1.0 \\
\hline St. Helena scrub and woodlands & 127 & 0.79 & 0.79 & 2 & 1 & 1 & 2.0 & 2.0 & 2.0 & 2.0 \\
\hline Sulawesi lowland rain forests & 116652 & 6.60 & 4.28 & 127 & 29 & 98 & 125.9 & 126.3 & 125.3 & 125.9 \\
\hline Sulawesi montane rain forests & 75909 & 0.07 & 0.06 & 98 & 21 & 77 & 98.0 & 98.0 & 98.0 & 98.0 \\
\hline Sulu Archipelago rain forests & 2363 & 30.77 & 25.86 & 33 & 5 & 28 & 31.5 & 31.8 & 30.7 & 31.1 \\
\hline Sumatran freshwater swamp forests & 18144 & 19.39 & 4.61 & 0 & 0 & 0 & 0.0 & 0.0 & 0.0 & 0.0 \\
\hline Sumatran lowland rain forests & 260064 & 2.65 & 1.27 & 33 & 3 & 30 & 32.9 & 32.9 & 32.8 & 32.9 \\
\hline Sumatran peat swamp forests & 87740 & 43.13 & 11.04 & 6 & 1 & 5 & 5.6 & 5.9 & 5.4 & 5.9 \\
\hline Sumba deciduous forests & 10796 & 2.77 & 1.82 & 15 & 3 & 12 & 14.9 & 15.0 & 14.9 & 14.9 \\
\hline Sunda Shelf mangroves & 37493 & 76.93 & 54.86 & 1 & 0 & 1 & 0.8 & 0.9 & 0.7 & 0.9 \\
\hline Sundaland heath forests & 76805 & 10.65 & 7.42 & 2 & 0 & 2 & 2.0 & 2.0 & 2.0 & 2.0 \\
\hline Taiheiyo evergreen forests & 138541 & 6.31 & 1.25 & 27 & 7 & 20 & 26.8 & 27.0 & 26.7 & 26.9 \\
\hline
\end{tabular}


Taiheiyo montane deciduous forests

Timor and Wetar deciduous forests

Tongan tropical moist forests

Trans Fly savanna and grasslands

Trinidad and Tobago moist forests

Tristan Da Cunha-Gough Islands shrub and grasslands

Trobriand Islands rain forests

Tuamotu tropical moist forests

Tubuai tropical moist forests

Vanuatu rain forests

Vogelkop montane rain forests

Vogelkop-Aru lowland rain forests

Western Java rain forests

Western Polynesian tropical moist forests

Windward Islands moist forests

Wrangel Island arctic desert

Yap tropical dry forests

Alaska Peninsula montane taiga

Alaska-St. Elias Range tundra

Aleutian Islands tundra

Atlantic coastal pine barrens

Baffin coastal tundra

Baja California desert

Belizian pine forests

Bering tundra

British Columbia mainland coastal forests

\begin{tabular}{|c|c|c|c|c|c|c|c|c|c|}
\hline 42047 & 0.15 & 0.02 & 13 & 0 & 13 & 13.0 & 13.0 & 13.0 & 13.0 \\
\hline 33607 & 3.32 & 2.26 & 47 & 7 & 40 & 46.8 & 46.9 & 46.7 & 46.8 \\
\hline 931 & 56.39 & 51.34 & 12 & 1 & 11 & 10.8 & 11.0 & 10.2 & 10.4 \\
\hline 26854 & 32.58 & 21.54 & 11 & 1 & 10 & 10.5 & 10.7 & 10.2 & 10.5 \\
\hline 4759 & 5.95 & 3.19 & 86 & 1 & 85 & 85.3 & 85.7 & 85.0 & 85.4 \\
\hline 161 & 1.86 & 0.62 & 7 & 1 & 6 & 7.0 & 7.0 & 7.0 & 7.0 \\
\hline 4207 & 23.72 & 18.75 & 13 & 2 & 11 & 12.6 & 12.7 & 12.3 & 12.5 \\
\hline 920 & 56.85 & 55.00 & 18 & 6 & 12 & 16.2 & 16.3 & 15.2 & 15.4 \\
\hline 141 & 17.02 & 13.48 & 4 & 1 & 3 & 3.9 & 3.9 & 3.9 & 3.9 \\
\hline 13218 & 12.56 & 0.00 & 50 & 14 & 36 & 49.2 & 50.0 & 48.7 & 50.0 \\
\hline 22033 & 0.35 & 41.37 & 31 & 4 & 27 & 31.0 & 29.0 & 31.0 & 27.9 \\
\hline 77454 & 17.01 & 1.40 & 30 & 1 & 29 & 29.3 & 29.9 & 28.9 & 29.9 \\
\hline 41660 & 10.71 & 4.67 & 14 & 0 & 14 & 13.8 & 13.9 & 13.7 & 13.9 \\
\hline 84 & 60.71 & 55.95 & 0 & 0 & 0 & 0.0 & 0.0 & 0.0 & 0.0 \\
\hline 2017 & 29.35 & 28.81 & 44 & 8 & 36 & 42.1 & 42.2 & 41.1 & 41.1 \\
\hline 7554 & 4.79 & 1.51 & 0 & 0 & 0 & 0.0 & 0.0 & 0.0 & 0.0 \\
\hline 97 & 20.62 & 4.12 & 11 & 2 & 9 & 10.7 & 10.9 & 10.5 & 10.9 \\
\hline 47871 & 3.45 & 2.79 & 0 & 0 & 0 & 0.0 & 0.0 & 0.0 & 0.0 \\
\hline 152249 & 0.10 & 0.08 & 0 & 0 & 0 & 0.0 & 0.0 & 0.0 & 0.0 \\
\hline 5499 & 5.76 & 5.16 & 8 & 3 & 5 & 7.9 & 7.9 & 8.0 & 8.0 \\
\hline 8975 & 15.08 & 1.25 & 2 & 1 & 1 & 2.0 & 2.0 & 2.0 & 2.0 \\
\hline 9110 & 5.97 & 4.24 & 0 & 0 & 0 & 0.0 & 0.0 & 0.0 & 0.0 \\
\hline 77875 & 4.24 & 0.27 & 95 & 5 & 90 & 94.5 & 95.0 & 94.4 & 95.0 \\
\hline 2829 & 2.44 & 0.35 & 130 & 0 & 130 & 129.6 & 129.9 & 129.4 & 129.9 \\
\hline 475307 & 1.54 & 0.54 & 0 & 0 & 0 & 0.0 & 0.0 & 0.0 & 0.0 \\
\hline 137478 & 0.63 & 0.45 & 0 & 0 & 0 & 0.0 & 0.0 & 0.0 & 0.0 \\
\hline
\end{tabular}

The original publication is available at www.springerlink.com | DOI: $10.1007 / \mathrm{s} 10531-010-9790-4$ 
California coastal sage and chaparral

California interior chaparral and woodlands

California montane chaparral and woodlands

Central American Atlantic moist forests

Central American dry forests

Central Pacific coastal forests

Cook Inlet taiga

Costa Rican seasonal moist forests

Davis Highlands tundra

Eastern Canadian forests

Eastern Canadian Shield taiga

Eastern forest-boreal transition

Eastern Great Lakes lowland forests

Everglades

Florida sand pine scrub

Gulf of California xeric scrub

Gulf of St. Lawrence lowland forests

Interior Alaska-Yukon lowland taiga

Jalisco dry forests

Kalaallit Nunaat high arctic tundra

Kalaallit Nunaat low arctic tundra

Middle Atlantic coastal forests

Miskito pine forests

Mississippi lowland forests

New England-Acadian forests

Newfoundland Highland forests

\begin{tabular}{|c|c|c|c|c|c|c|c|c|c|}
\hline 36377 & 1.40 & 0.45 & 35 & 5 & 30 & 34.9 & 35.0 & 34.9 & 35.0 \\
\hline 64665 & 1.27 & 0.38 & 14 & 3 & 11 & 14.0 & 14.0 & 14.0 & 14.0 \\
\hline 20515 & 0.12 & 0.03 & 8 & 2 & 6 & 8.0 & 8.0 & 8.0 & 8.0 \\
\hline 89717 & 2.59 & 0.91 & 174 & 4 & 170 & 173.4 & 173.8 & 173.1 & 173.7 \\
\hline 68248 & 2.14 & 0.36 & 191 & 1 & 190 & 190.5 & 190.9 & 190.2 & 190.9 \\
\hline 73892 & 1.26 & 0.32 & 8 & 2 & 6 & 8.0 & 8.0 & 8.0 & 8.0 \\
\hline 27893 & 2.71 & 1.22 & 0 & 0 & 0 & 0.0 & 0.0 & 0.0 & 0.0 \\
\hline 10712 & 0.69 & 0.35 & 195 & 0 & 195 & 194.8 & 194.9 & 194.7 & 194.9 \\
\hline 88024 & 2.40 & 2.16 & 0 & 0 & 0 & 0.0 & 0.0 & 0.0 & 0.0 \\
\hline 487966 & 2.43 & 1.59 & 2 & 1 & 1 & 2.0 & 2.0 & 2.0 & 2.0 \\
\hline 755343 & 1.18 & 0.77 & 0 & 0 & 0 & 0.0 & 0.0 & 0.0 & 0.0 \\
\hline 348450 & 0.00 & 0.00 & 0 & 0 & 0 & 0.0 & 0.0 & 0.0 & 0.0 \\
\hline 116727 & 0.08 & 0.01 & 1 & 0 & 1 & 1.0 & 1.0 & 1.0 & 1.0 \\
\hline 20149 & 91.21 & 9.38 & 2 & 0 & 2 & 1.5 & 2.0 & 1.4 & 2.0 \\
\hline 3876 & 21.88 & 1.39 & 5 & 0 & 5 & 4.8 & 5.0 & 4.8 & 5.0 \\
\hline 23641 & 2.15 & 1.00 & 119 & 18 & 101 & 118.7 & 118.9 & 118.6 & 118.8 \\
\hline 39455 & 3.74 & 0.74 & 0 & 0 & 0 & 0.0 & 0.0 & 0.0 & 0.0 \\
\hline 444388 & 0.41 & 0.16 & 0 & 0 & 0 & 0.0 & 0.0 & 0.0 & 0.0 \\
\hline 26126 & 2.39 & 0.57 & 176 & 2 & 174 & 175.5 & 175.9 & 175.2 & 175.8 \\
\hline 304455 & 1.54 & 1.14 & 0 & 0 & 0 & 0.0 & 0.0 & 0.0 & 0.0 \\
\hline 171449 & 6.16 & 5.22 & 0 & 0 & 0 & 0.0 & 0.0 & 0.0 & 0.0 \\
\hline 133839 & 23.86 & 5.42 & 3 & 1 & 2 & 2.9 & 3.0 & 2.9 & 3.0 \\
\hline 18904 & 16.30 & 3.03 & 128 & 0 & 128 & 125.2 & 127.5 & 123.5 & 127.2 \\
\hline 112551 & 13.76 & 1.83 & 0 & 0 & 0 & 0.0 & 0.0 & 0.0 & 0.0 \\
\hline 238049 & 0.62 & 0.27 & 1 & 0 & 1 & 1.0 & 1.0 & 1.0 & 1.0 \\
\hline 16394 & 0.29 & 0.16 & 0 & 0 & 0 & 0.0 & 0.0 & 0.0 & 0.0 \\
\hline
\end{tabular}




Northeastern coastal forests
Northern California coastal forests
Northern Canadian Shield taiga
Northern Pacific coastal forests
Northwest Territories taiga
Pacific Coastal Mountain icefields and tundra
Panamanian dry forests
Pantanos de Centla
PetenPeten-Veracruz moist forests
Puget lowland forests
Queen Charlotte Islands
San Lucan xeric scrub
Sierra de la Laguna dry forests
Sierra de los Tuxtlas
Sorngat Mountain tundra
Soutra Madre de Chiapas moist forests
Southaloan dry forests
Sonoran desert
Sonoran-Sinaloan transition subtropicasical dry forest

\begin{tabular}{|c|c|c|c|c|c|c|c|c|c|}
\hline 89895 & 3.23 & 0.31 & 0 & 0 & 0 & 0.0 & 0.0 & 0.0 & 0.0 \\
\hline 13292 & 1.35 & 0.15 & 9 & 2 & 7 & 9.0 & 9.0 & 9.0 & 9.0 \\
\hline 614970 & 0.01 & 0.00 & 0 & 0 & 0 & 0.0 & 0.0 & 0.0 & 0.0 \\
\hline 60613 & 4.90 & 3.10 & 0 & 0 & 0 & 0.0 & 0.0 & 0.0 & 0.0 \\
\hline 346639 & 2.21 & 2.16 & 0 & 0 & 0 & 0.0 & 0.0 & 0.0 & 0.0 \\
\hline 107055 & 0.56 & 0.34 & 0 & 0 & 0 & 0.0 & 0.0 & 0.0 & 0.0 \\
\hline 5141 & 4.20 & 0.29 & 144 & 0 & 144 & 143.2 & 143.9 & 142.8 & 143.9 \\
\hline 17209 & 42.67 & 9.61 & 126 & 0 & 126 & 117.6 & 124.4 & 112.8 & 123.5 \\
\hline 149472 & 2.67 & 0.73 & 298 & 17 & 281 & 297.0 & 297.7 & 296.4 & 297.6 \\
\hline 22551 & 3.89 & 0.95 & 0 & 0 & 0 & 0.0 & 0.0 & 0.0 & 0.0 \\
\hline 10001 & 2.21 & 1.71 & 0 & 0 & 0 & 0.0 & 0.0 & 0.0 & 0.0 \\
\hline 3902 & 3.02 & 1.28 & 69 & 0 & 69 & 68.7 & 68.9 & 68.7 & 68.9 \\
\hline 3994 & 0.23 & 0.13 & 59 & 1 & 58 & 59.0 & 59.0 & 59.0 & 59.0 \\
\hline 3882 & 4.56 & 1.98 & 157 & 9 & 148 & 156.1 & 156.6 & 155.5 & 156.4 \\
\hline 11290 & 0.25 & 0.00 & 196 & 5 & 191 & 195.9 & 196.0 & 195.9 & 196.0 \\
\hline 77810 & 2.35 & 0.12 & 185 & 7 & 178 & 184.5 & 185.0 & 184.3 & 185.0 \\
\hline 223498 & 1.60 & 0.05 & 59 & 6 & 53 & 58.9 & 59.0 & 58.9 & 59.0 \\
\hline 51153 & 1.82 & 0.30 & 0 & 0 & 0 & 0.0 & 0.0 & 0.0 & 0.0 \\
\hline 2043 & 22.17 & 13.12 & 0 & 0 & 0 & 0.0 & 0.0 & 0.0 & 0.0 \\
\hline 2076 & 96.10 & 7.76 & 4 & 1 & 3 & 2.7 & 4.0 & 2.4 & 4.0 \\
\hline 237108 & 7.34 & 0.64 & 28 & 8 & 20 & 27.7 & 28.0 & 27.7 & 28.0 \\
\hline 348535 & 0.35 & 0.11 & 9 & 0 & 9 & 9.0 & 9.0 & 9.0 & 9.0 \\
\hline 374503 & 6.59 & 3.16 & 0 & 0 & 0 & 0.0 & 0.0 & 0.0 & 0.0 \\
\hline 42597 & 2.68 & 1.77 & 254 & 9 & 245 & 253.1 & 253.4 & 252.6 & 253.1 \\
\hline 32360 & 0.62 & 0.47 & 0 & 0 & 0 & 0.0 & 0.0 & 0.0 & 0.0 \\
\hline 6655 & 1.98 & 0.53 & 112 & 2 & 110 & 111.7 & 111.9 & 111.6 & 1.9 \\
\hline
\end{tabular}




\begin{tabular}{|c|c|c|c|c|c|c|c|c|c|c|c|}
\hline & Veracruz moist forests & 69276 & 1.50 & 0.78 & 172 & 7 & 165 & 171.7 & 171.8 & 171.6 & 171.8 \\
\hline & Western Gulf coastal grasslands & 80784 & 43.88 & 12.27 & 8 & 1 & 7 & 7.4 & 7.9 & 7.3 & 7.8 \\
\hline & Willamette Valley forests & 14881 & 0.27 & 1.33 & 4 & 2 & 2 & 4.0 & 4.0 & 4.0 & 4.0 \\
\hline & Yucatán dry forests & 49791 & 9.46 & 1.28 & 138 & 5 & 133 & 136.3 & 137.8 & 135.3 & 137.6 \\
\hline & Yucatán moist forests & 69865 & 8.39 & 2.14 & 148 & 4 & 144 & 146.4 & 147.6 & 145.4 & 147.4 \\
\hline \multirow[t]{21}{*}{ South America } & Alto Paraná Atlantic forests & 485025 & 0.25 & 0.15 & 210 & 0 & 210 & 209.9 & 210.0 & 209.9 & 209.9 \\
\hline & Araya and Paria xeric scrub & 5234 & 5.77 & 3.65 & 142 & 0 & 142 & 141.0 & 141.3 & 140.3 & 141.0 \\
\hline & Atacama desert & 105425 & 0.03 & 0.01 & 38 & 1 & 37 & 38.0 & 38.0 & 38.0 & 38.0 \\
\hline & Atlantic Coast restingas & 7887 & 45.61 & 23.39 & 124 & 3 & 121 & 115.0 & 120.0 & 109.8 & 117.6 \\
\hline & Bahia coastal forests & 109935 & 3.94 & 2.12 & 172 & 6 & 166 & 171.1 & 171.5 & 170.6 & 171.3 \\
\hline & Bahia interior forests & 230250 & 0.19 & 0.09 & 191 & 3 & 188 & 191.0 & 191.0 & 190.9 & 191.0 \\
\hline & Caatinga & 736057 & 0.37 & 0.19 & 138 & 5 & 133 & 137.9 & 138.0 & 137.9 & 137.9 \\
\hline & Catatumbo moist forests & 22908 & 2.72 & 0.05 & 188 & 3 & 185 & 187.4 & 188.0 & 187.0 & 188.0 \\
\hline & Chilean matorral & 148799 & 0.24 & 0.14 & 90 & 13 & 77 & 90.0 & 90.0 & 90.0 & 90.0 \\
\hline & Chocó-Darién moist forests & 73739 & 4.76 & 2.16 & 413 & 39 & 374 & 410.5 & 411.9 & 409.0 & 411.2 \\
\hline & Cordillera La Costa montane forests & 14299 & 0.04 & 0.01 & 264 & 28 & 236 & 264.0 & 264.0 & 264.0 & 264.0 \\
\hline & Ecuadorian dry forests & 21329 & 1.37 & 0.69 & 120 & 0 & 120 & 119.8 & 119.9 & 119.7 & 119.8 \\
\hline & Espinal & 115822 & 1.32 & 0.64 & 50 & 1 & 49 & 49.9 & 50.0 & 49.9 & 50.0 \\
\hline & Guajira-Barranquilla xeric scrub & 31699 & 6.54 & 2.02 & 166 & 1 & 165 & 164.6 & 165.6 & 163.8 & 165.3 \\
\hline & Guayaquil flooded grasslands & 2936 & 1.40 & 0.20 & 70 & 0 & 70 & 69.9 & 70.0 & 69.8 & 70.0 \\
\hline & Guianan freshwater swamp forests & 7769 & 46.31 & 17.51 & 107 & 0 & 107 & 99.1 & 104.5 & 94.5 & 103.0 \\
\hline & Guianan moist forests & 513982 & 2.37 & 1.02 & 301 & 22 & 279 & 300.1 & 300.6 & 299.6 & 300.4 \\
\hline & Humid Pampas & 241336 & 3.92 & 0.06 & 69 & 4 & 65 & 68.7 & 69.0 & 68.6 & 69.0 \\
\hline & Isthmian-Atlantic moist forests & 59026 & 2.30 & 0.42 & 248 & 7 & 241 & 247.3 & 247.9 & 246.9 & 247.8 \\
\hline & Isthmian-Pacific moist forests & 29332 & 3.11 & 1.42 & 242 & 9 & 233 & 241.1 & 241.6 & 240.5 & 241.3 \\
\hline & La costa xeric shrublands & 68652 & 0.47 & 0.21 & 172 & 2 & 170 & 171.9 & 172.0 & 171.8 & 171.9 \\
\hline
\end{tabular}




\begin{tabular}{|c|c|c|c|c|c|c|c|c|c|c|}
\hline Lara-Falcón dry forests & 16991 & 1.92 & 0.98 & 151 & 1 & 150 & 150.6 & 150.8 & 150.4 & 150.7 \\
\hline Llanos & 390017 & 0.72 & 0.22 & 203 & 8 & 195 & 202.8 & 202.9 & 202.7 & 202.9 \\
\hline Magdalena-Urabá moist forests & 76945 & 0.73 & 0.26 & 210 & 2 & 208 & 209.8 & 209.9 & 209.7 & 209.9 \\
\hline Magellanic subpolar forests & 147671 & 5.85 & 4.66 & 51 & 3 & 48 & 50.6 & 50.7 & 50.5 & 50.6 \\
\hline Malpelo Island xeric scrub & 10 & 30.00 & 20.00 & 5 & 2 & 3 & 4.8 & 4.9 & 4.7 & 4.8 \\
\hline Maracaibo dry forests & 30285 & 3.04 & 1.42 & 163 & 2 & 161 & 162.4 & 162.7 & 162.0 & 162.5 \\
\hline Marajó varzea & 88814 & 78.12 & 56.54 & 101 & 1 & 100 & 83.7 & 91.1 & 74.6 & 85.6 \\
\hline Maranhão Babaru forests & 142695 & 2.15 & 5.59 & 113 & 0 & 113 & 112.7 & 112.2 & 112.5 & 111.7 \\
\hline Northeastern Brazil restingas & 10142 & 19.70 & 9.64 & 107 & 0 & 107 & 104.1 & 105.7 & 102.4 & 104.9 \\
\hline Orinoco Delta swamp forests & 28196 & 69.56 & 62.80 & 183 & 2 & 181 & 157.9 & 161.9 & 144.4 & 150.3 \\
\hline Orinoco wetlands & 6027 & 64.13 & 50.79 & 143 & 0 & 143 & 125.9 & 131.0 & 116.6 & 124.2 \\
\hline Paraguana xeric scrub & 15941 & 5.66 & 2.05 & 156 & 2 & 154 & 154.9 & 155.6 & 154.2 & 155.4 \\
\hline Paranß Parana flooded savanna & 38935 & 34.76 & 10.74 & 77 & 1 & 76 & 73.0 & 75.9 & 72.1 & 75.7 \\
\hline Patagonian steppe & 488379 & 0.25 & 0.00 & 112 & 22 & 90 & 112.0 & 112.0 & 112.0 & 112.0 \\
\hline Pernambuco coastal forests & 17648 & 4.28 & 3.51 & 129 & 5 & 124 & 128.3 & 128.4 & 127.9 & 128.1 \\
\hline Pernambuco interior forests & 22731 & 4.87 & 2.43 & 114 & 0 & 114 & 113.3 & 113.7 & 112.9 & 113.4 \\
\hline Sechura desert & 185332 & 2.34 & 1.66 & 132 & 20 & 112 & 131.6 & 131.7 & 131.4 & 131.6 \\
\hline Serra do Mar coastal forests & 105163 & 3.60 & 2.00 & 217 & 9 & 208 & 216.0 & 216.5 & 215.4 & 216.1 \\
\hline Sin. u Valley dry forests & 25113 & 4.28 & 0.21 & 191 & 6 & 185 & 190.0 & 191.0 & 189.3 & 190.9 \\
\hline Tapajós-Xingu moist forests & 337258 & 0.08 & 0.01 & 164 & 1 & 163 & 164.0 & 164.0 & 164.0 & 164.0 \\
\hline Tocantins/Pindare moist forests & 194130 & 5.96 & 1.77 & 150 & 1 & 149 & 148.9 & 149.7 & 148.2 & 149.5 \\
\hline Tumbes-Piura dry forests & 41391 & 0.82 & 0.14 & 150 & 7 & 143 & 149.8 & 150.0 & 149.8 & 150.0 \\
\hline Uatuma-Trombetas moist forests & 474271 & 0.64 & 0.11 & 175 & 0 & 175 & 174.9 & 175.0 & 174.8 & 175.0 \\
\hline Uruguayan savanna & 356488 & 1.86 & 0.58 & 100 & 4 & 96 & 99.8 & 99.9 & 99.7 & 99.9 \\
\hline Valdivian temperate forests & 248645 & 2.46 & 1.73 & 104 & 18 & 86 & 103.7 & 103.8 & 103.6 & 103.7 \\
\hline Venezuelan Andes montane forests & 29449 & 2.40 & 4.61 & 296 & 30 & 266 & 295.1 & 294.3 & 294.6 & 293.2 \\
\hline
\end{tabular}


Menon et al. Biodiversity consequences of sea level rise

\begin{tabular}{|c|c|c|c|c|c|c|c|c|c|c|c|}
\hline & Western Ecuador moist forests & 34212 & 1.99 & 0.04 & 278 & 16 & 262 & 277.3 & 278.0 & 276.9 & 278.0 \\
\hline & Xingu-Tocantins-Araguaia moist forests & 266888 & 9.89 & 5.23 & 155 & 1 & 154 & 153.0 & 154.0 & 151.8 & 153.4 \\
\hline Global & Rock and Ice & 11028604 & 0.03 & 0.02 & 0 & 0 & 0 & 0.0 & 0.0 & 0.0 & 0.0 \\
\hline
\end{tabular}

